\title{
Uma "exploração arqueológica" da ideia de vazio como recipiente a partir de Aristóteles, Physica 4.6 213a15-19
}

Gustavo Laet Gomes

Even though rejecting the notion of void, Aristotle considers it a crucial theme in his discussion about motion. That becomes evident when we find four chapters of Physics 4 dedicated to the discussion and refutation of the void. In this paper, I set on an exploratory search for the reasons

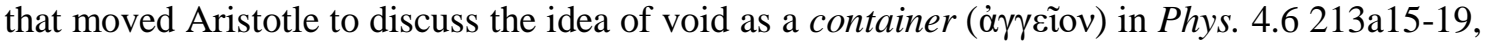
unearthing a series of terms and notions used by previous thinkers that may have led Aristotle to formulate such conception. Special attention is given to Democritus, who, with his theory of atoms and void, is clearly the main target of Aristotle's criticism of the void. I conclude that the notion of void as a container is not at all strange to ancient thinkers, and that its reconstitution by Aristotle is everything but trivial and simplistic, inasmuch as the Democritean notion of void he intends to refute is everything but trivial and simplistic.

Nos capítulos 6 a 9 do livro 4 da Física, Aristóteles apresenta sua mais extensa discussão a respeito do tema do vazio. Nas primeiras linhas do capítulo 6 (213a12-15) ele anuncia a importância deste tópico para o pensador naturalista e equipara sua importância ao estudo da noção de lugar, que ocupou os primeiros cinco capítulos do livro 4. Tal importância parece residir no fato de que o vazio costuma ser mobilizado em explicações a respeito do movimento, assumindo um papel que pode ser confundido com o da noção aristotélica de lugar, de modo que os dois tópicos - vazio e lugar - não podem ser totalmente dissociados.

A questão do vazio interessa obviamente ao estudo do atomismo de Leucipo e Demócrito, já que ele é apontado, junto com os átomos, como um dos princípios elementares de tal teoria. De fato, esses dois pensadores parecem ser os mais visados na discussão de Aristóteles e são mencionados explicitamente no capítulo 6, como defensores de um vazio que quebra a continuidade do que é corpo, junto com "muitos 
outros naturalistas" (213a31-b1), a respeito dos quais não é claro se defendem o vazio ou apenas a descontinuidade do que é corpo.

Não obstante, não é incomum que alguns estudiosos do atomismo tomem uma definição que Aristóteles sugere no capítulo 7 como sendo a posição que ele atribui a Leucipo e Demócrito:

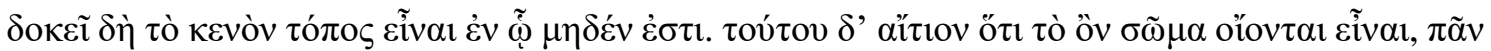

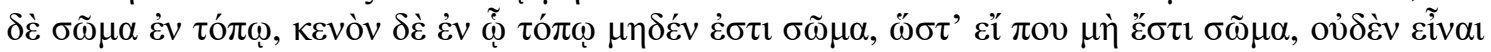

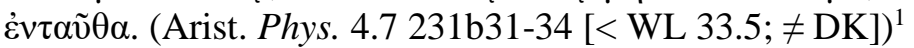

$\mathrm{O}$ vazio, então, parece ser um lugar no qual não há nada. E a causa disso é porque pensam que oque-é é corpo, e que todo corpo é ${ }^{2}$ em um lugar, e que vazio é o lugar em que não há corpo algum, de modo que, se em algum lugar não há corpo, então não há nada ali. ${ }^{3}$

É o caso de David Sedley (1982, p. 179 e n. 10 [p. 191-192]), que vê nisso uma estratégia aristotélica para refutar o vazio, que poderia ser resumida mais ou menos assim: Se Demócrito pensa o vazio como um lugar sem corpo, isso implicaria em entendê-lo como uma distância entre corpos, ou seja, uma extensão espacial em que não há corpos. Aristóteles, então, refutaria - dentro dos parâmetros de sua teoria do lugar - a existência de tal extensão espacial vazia e, com isso, também o vazio, que não poderia existir enquanto tal ( $c f$. Phys. 4.7 214a16-31). Para Sedley, ao que parece, o procedimento aristotélico implicaria que o vazio não pode ser entendido como espaço, porque seria o próprio Aristóteles o primeiro a fazer tal assimilação entre vazio e espaço ao interpretar o vazio democritiano como lugar. A partir desta conclusão, Sedley encontraria margem para pensar que o próprio vazio de Demócrito também fosse um "ocupador de espaço" e qualquer coisa substancial (uma "substância negativa"), ainda que em grau menor do que os átomos (Sedley, 1982, p. 175-176, 179-180).

\footnotetext{
${ }^{1}$ Indicarei as passagens relativas a pensadores pré-socráticos preferencialmente pela coleção de Laks \& Most (Early Greek Philosophy. 9 vols. Cambridge: Harvard University Press 2016), sigla LM, indicando também a equivalência em Diels-Kranz (Diels, H. Die Fragmente der Vorsokratiker. 6th ed. (rev. by Walther Kranz). Berlin: Weidmann 1952), sigla DK. Nos casos em que um determinado trecho não constar em nenhuma das duas, poderá ser indicada, uma coleção alternativa como WL (Leszl, W. I Primi Atomisti. Raccolta dei testi che riguardano Leucippo e Democrito. Firenze: Leo S. Olschki 2009) ou SL (Luria, S. Y. Democrito. Tradução de Diego Fusaro e Anastasia Krivushina. $2^{a}$ ed. Milano: Bompiani 2014), além da indicação de que não consta em DK. Utilizo ainda os sinais $<,>\mathrm{e}=$ para indicar o modo de correspondência do texto citado com o fragmento. $\neq$ indica que o texto não aparece na coletânea indicada.

${ }^{2}$ Tomei deliberadamente a decisão de não supor o verbo estar. Me parece que não se trata de um problema de posição, mas de existência, como se, para algo existir, fosse necessária a existência prévia de uma sede que funciona como uma espécie de palco, como veremos abaixo.

${ }^{3}$ Todas as traduções são minhas.
} 
Sedley, porém, não se demora sobre os argumentos que levam Aristóteles a sugerir a semelhança entre vazio e lugar na Física, remetendo-se à análise de Friedrich Solmsen (Aristotle's System of the Physical World. Ithaca: Cornell University Press 1960, p. 140142), para quem a assimilação entre vazio e lugar seria uma espécie de inovação aristotélica adotada apenas no atomismo de Epicuro (Solmsen, 1960, p. 141). ${ }^{4}$ De fato, há um único fragmento de Epicuro, transmitido por Plutarco (Adv. Col. 11 1112E [fr. 76

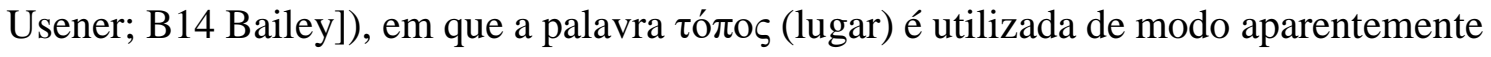
intercambiável com $\kappa \varepsilon v o ́ v\left(\right.$ vazio). ${ }^{5}$

A questão é se Solmsen está, de fato, descartando a hipótese do vazio como espaço ou apenas a assimilação entre vazio e a noção, agora sim, aristotélica de lugar, ${ }^{6}$ que, como se sabe, é bem distante da ideia de lugar que permeia o senso comum e, definitivamente não é a de lugar como espaço. Rejeitar a ideia de vazio como lugar aristotélico não significa, portanto, rejeitar a noção de vazio como espaço. Significa rejeitar a noção de vazio como um dos elementos necessários para descrever um determinado movimento, a

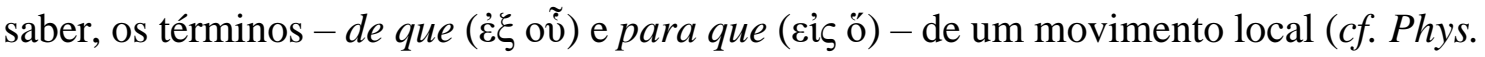
5.1 224a34-b1). Significa ainda rejeitar o vazio como ente físico existente, pois, para Aristóteles o lugar é um limite (do corpo móvel) e, como tal, não deve ser contado entre os entes naturais, pois não tem uma existência independente do corpo móvel. Mas este

\footnotetext{
${ }^{4}$ Ver ainda Morel, P.-M. Démocrite et la recherche des causes. Paris: Klincksieck 1996, p. 65 \& n. 65, que também recorre a Solmsen e diz que "Aristote néglige assurément, dans la réfutation des partisans du vide, la richesse su concept démocritéen" ao apresentar "le vide abdéritain comme une conception erronée du lieu".

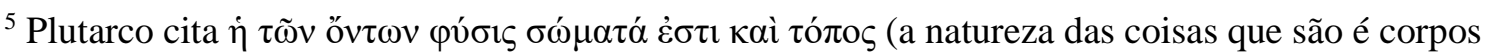
e lugar), mas em seguida toda a discussão com Colotes não utiliza mais a palavra tó

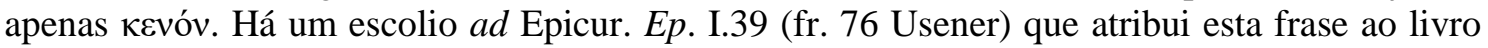

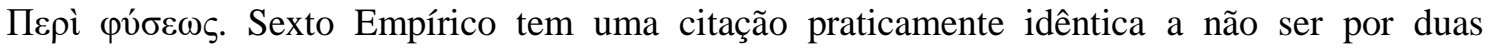

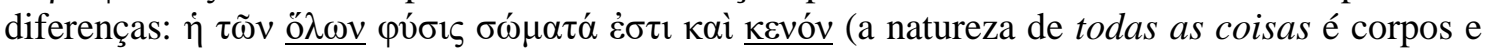

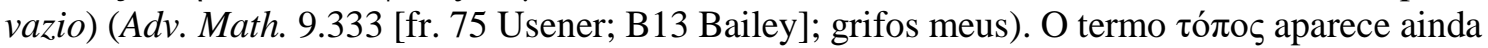
em outros dois testemunhos (mencionados em nota ao fr. 76 Usener): Philod. Piet. 2.81 (p. 111

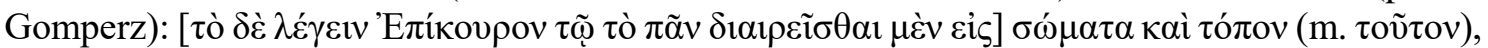

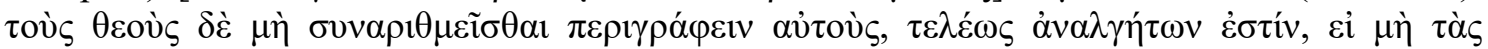

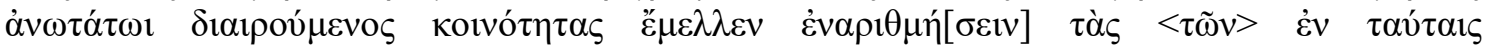

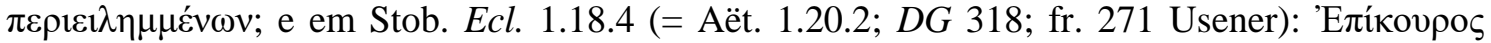

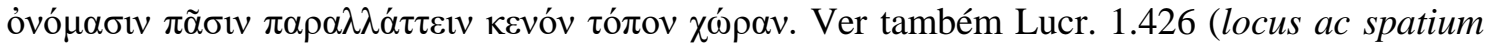
quod inane uocamus [lugar ou espaço, aquilo a que chamamos vazio]), 954-955 (item quod inane repertumst / seu locus ac spatium, res in quo quaeque gerantur [também o vazio que foi encontrado - ou lugar, ou espaço - no qual se geram todas as coisas]).

${ }^{6}$ A segunda opção parece mais ser o caso, pois ele diz que é Aristóteles que "likes to think of the void as a place" (Solmsen, 1960, p. 141).
} 
não é o caso do vazio democritiano, que é um ente natural independente e completamente distinto dos átomos.

Ao contrário de Sedley, podemos imaginar um Aristóteles cuidadoso que, diante da sua concepção própria e bastante peculiar de lugar, alerta que igualar vazio e lugar é um erro e que aqueles que o fazem estão pensando justamente em lugar como um espaço que pode estar cheio (i.e. ocupado) ou vazio (i.e. não ocupado). Por esta leitura teríamos uma associação entre vazio e lugar anterior à concepção aristotélica de lugar e compatível com certo senso comum. Seria muito desonesto da parte da Aristóteles introduzir uma concepção nova de lugar e simplesmente refutar todas as demais noções associadas à concepção anterior de lugar. Mas este não parece ser o caso, pois Aristóteles toma o cuidado de fazer um levantamento bem representativo em Phys. 4.6 de certos usos do termo 'vazio' correntes em sua época. O processo refutatório que se inicia no capítulo 7 tem como objetivo assegurar que não há necessidade de uma concepção de vazio para se pensar o movimento e a mudança, e é por isso que é tão importante rejeitar a associação entre vazio e lugar, e mais adiante, no capítulo 9, entre vazio e matéria.

Mas se Aristóteles não está simplesmente dizendo que, para Demócrito e Leucipo, o vazio é um lugar, o que é possível extrair de sua longa discussão sobre o vazio? Acredito, diferentemente de Sedley e Morel, que há muito o que aprender, a partir da tentativa de Aristóteles de compreender as noções de vazio entre seus predecessores, especialmente no capítulo 6. Meu intuito nas próximas páginas é registrar a primeira etapa de um processo de coleta e análise de uma série de possíveis sentidos da palavra e da ideia de vazio que estão presentes ou pressupostas em Phys. 4.6, e até mesmo eventuais noções que podem estar embutidas nesses sentidos sem que o próprio Aristóteles tenha se dado conta delas. Começando pela primeira afirmação do capítulo que tenta qualificar o vazio, a ideia é fazer uma espécie de arqueologia desses sentidos, partindo principalmente de etimologias e da análise de termos derivados ou termos dos quais certas palavras utilizadas por Aristóteles derivam, supondo com isso, que os termos derivados carreguem voluntária ou involuntariamente algum sentido mais "ancestral", o que talvez possa ajudar a ampliar nossa compreensão da noção de vazio, agora sim, especialmente aquela de Demócrito que, para todos os efeitos, é o principal adepto desta noção na antiguidade. Minha ideia é empregar o mesmo procedimento para todos os 4 capítulos. Neste trabalho me restringirei a Phys. 4.6 213a15-19 numa tentativa de testar o conceito, focando especificamente nos desdobramentos da ideia de vazio como recipiente ( $\dot{\alpha} \gamma \gamma \varepsilon i ̃ o v)$. 
Temos notícia de que Demócrito teria empregado vários termos para se referir ao que se convencionou denominar como "o vazio" ( $c f$., por exemplo, Arist. apud Simpl. in Cael 295.11-12 [< LM27 D29; < DK68 A37], o fragmento do tratado perdido de Aristóteles Sobre Demócrito). A tradição adotou o adjetivo substantivado 'vazio', como designação preferencial, bem como o termo ‘átomo’ para se referir ao princípio oposto. Embora eu vá utilizar aqui eventualmente 'vazio' e 'átomos' para se referir a essas noções, quero deixar aberta a possibilidade de que o mais correto talvez fosse manter esses termos como adjetivos e que os entes a que eles se referem talvez sejam mais difíceis de apreender do que sugerem à primeira vista esses adjetivos substantivados, que têm o estranho poder de convertê-los em substâncias quase aristotélicas. Essa ambiguidade morfológica do termo 'vazio' aparece já no início de Phys. 4.6:

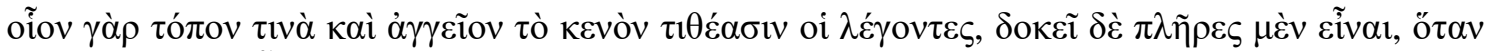

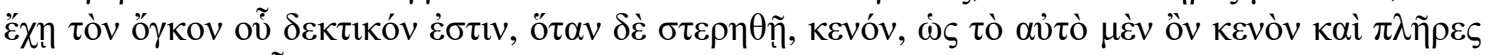

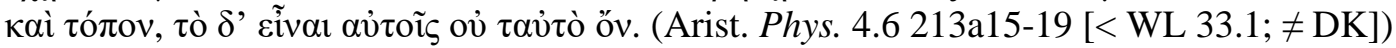

Pois aqueles que falam do vazio apresentam-no tal qual um certo lugar ou um recipiente, que parece estar cheio quando contém a massa que é capaz de receber e vazio quando [esta massa] é removida, como se vazio, cheio e lugar fossem o mesmo, mas o ser dessas coisas não é o mesmo.

Neste trecho, em que Aristóteles apresenta, digamos assim, uma primeira impressão

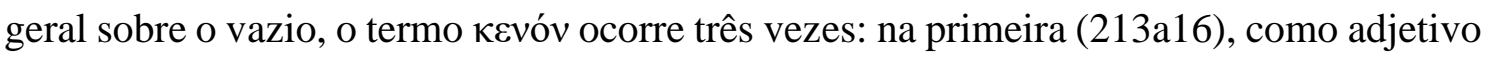
substantivado (objeto direto do particípio $\lambda \varepsilon ́ \gamma o v \tau \varepsilon \varsigma$ ); na segunda (213a18), como adjetivo (predicativo verbal do infinitivo eĩval); e, na terceira (também em 213a18), a situação é propositalmente ambígua justamente para gerar a aporia: 'vazio' e 'cheio' são obviamente adjetivos, mas 'lugar' não e esse é naturalmente um dos motivos pelos quais “o ser dessas coisas não é o mesmo".

Parece, portanto, que o termo 'vazio' designa antes de tudo uma característica de

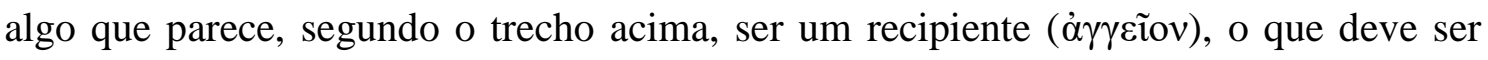
provavelmente sua principal característica, de modo que seus proponentes se refeririam a esta coisa que é, antes de tudo, vazia, como 'o vazio'. Como recipiente, ele pode, inclusive, estar cheio, que é a característica oposta. Portanto, o vazio (adjetivo substantivado) pode estar vazio (adjetivo) ou estar cheio.

A partir desta chave, que é tomar 'vazio' como sendo primariamente um predicado de alguma coisa, e não uma substância com uma essência muito bem demarcada, vejamos, então, que outras características desta coisa podem ser depreendidas a partir de seus primeiros predicados encontrados nesta passagem de Phys. 4.6. 


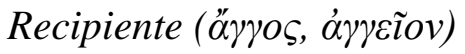

O primeiro aspecto, e um dos mais importantes ocorre, como vimos, já na primeira oração: "os que falam do vazio o apresentam tal qual um certo lugar ou um recipiente" (213a15-16). Esta sentença não indica que Aristóteles esteja afirmando que os postulantes do vazio dizem que ele é um lugar, mas que o modo pelo qual eles falam do vazio o faz

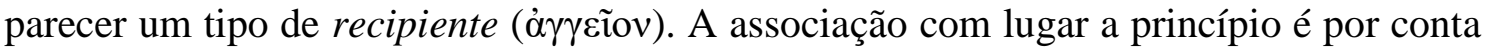
de Aristóteles, que já tinha notado antes que, em certo sentido, um lugar funciona como um recipiente por ser separado ( $\chi \omega \rho ı \tau \tau o ́ \varsigma)$ da coisa que ele contém (Phys. 4.2 209b2730). Que a ideia principal aqui é a de recipiente fica claro na sentença seguinte (4.6 213a16-18), onde ele explica em que sentido o vazio, tal como é apresentado, se comportaria como um recipiente: ele é dito cheio quando parece conter algo - uma massa

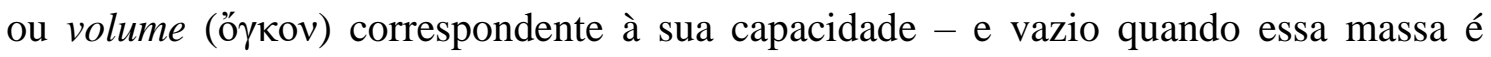
removida e, portanto, não ocupa mais o volume correspondente à sua capacidade.

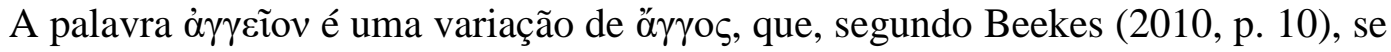
refere a vasilhames utilizados principalmente na cozinha e tem provavelmente origem mediterrânea. Como um vasilhame deste tipo, sua principal função é guardar e eventualmente transportar alimentos ( $c f$. Phys. 4.3210 b11). Em seu sentido mais técnico,

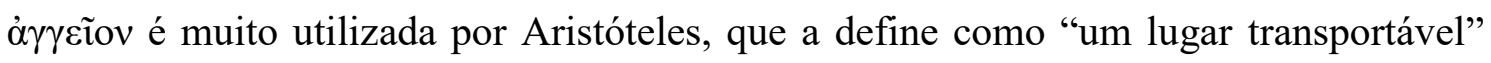

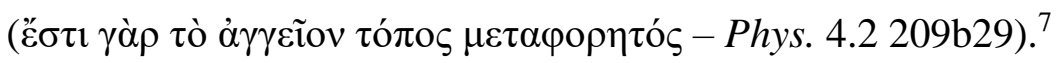

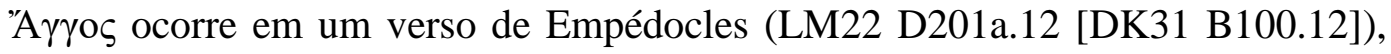
empregado com o sentido de recipiente na bela cena de uma criança brincando com uma clepsidra (v. 9-21) que ora contém ar, ora contém água. Não há outras ocorrências do termo em fragmentos, mas temos alguns casos interessantes em alguns testemunhos.

Hecateu de Abdera, por exemplo, historiador e filósofo, discípulo de Pirro, contemporâneo de Aristóteles, descreve em DK73 B7 (apud Diod. Sic. 1.11.1, 5-6; 12.12, 3-7) uma teoria cosmológica egípcia, supostamente antiga, segundo a qual o todo é regido e de certo modo composto por sol e lua, identificados com Osíris e Ísis, e que estes são constituídos a partir de cinco elementos: sopro $(\pi v \varepsilon \tilde{u} \mu \alpha)$, fogo, seco, úmido e aéreo

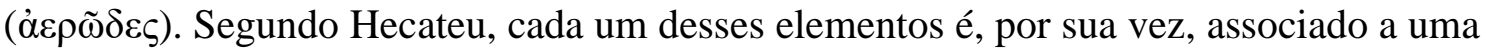

\footnotetext{
${ }^{7}$ Sobre este sentido técnico, ver também Phys. 4.3211 b26 (um recipiente que muda de lugar transportando o seu conteúdo, mas as partes da coisa que o recipiente contém permanecem em seus lugares) e 4.4 212a13-17 (se um recipiente pode ser entendido como um lugar móvel, o lugar pode ser entendido como um recipiente que não pode ser movido).
} 
divindade grega. O sopro é chamado Zeus, o fogo é chamado Hefesto, o úmido é chamado Oceano e o ar (no lugar do "aéreo") é chamado Atena. Já o elemento seco aparece substituído por terra, que é chamada Mãe "por acolher, como um recipiente, as coisas que

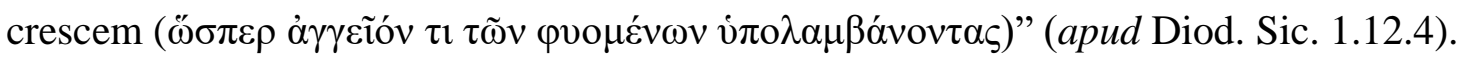

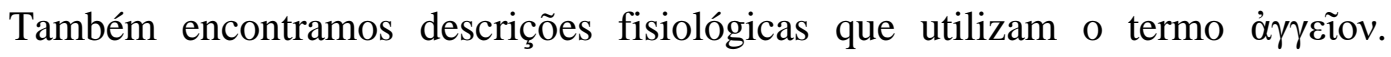
Pseudo-Plutarco, por exemplo, descreve que, para Empédocles,

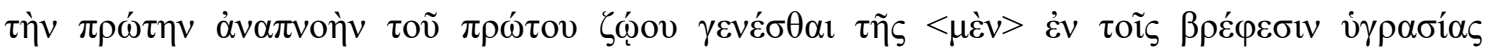

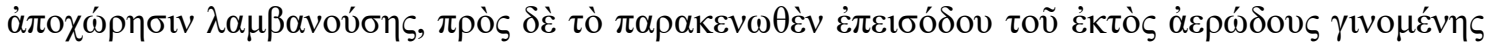

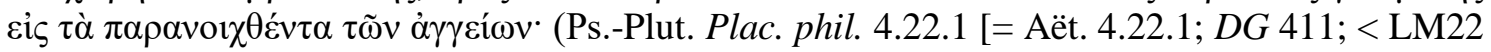
D170b; <DK31 A74])

a primeira inspiração do primeiro ser vivo ocorreu a partir da saída do [elemento] aquoso [que estava] nos embriões e pela entrada do [elemento] aéreo externo no vazio resultante, através das aberturas dos vasos.

Esta descrição lembra em alguma medida o funcionamento da clepsidra, pois a saída do líquido de dentro dos embriões gera uma diferença de pressão que faz com que o ar a preencha imediatamente. Os vasos aqui permitem a passagem de algo de dentro para fora do corpo e de fora para dentro. ${ }^{8}$

Em Cael. 3.7 305a33-b19 (WL 18.6 + 48.7; > DK68 A46a), mencionando

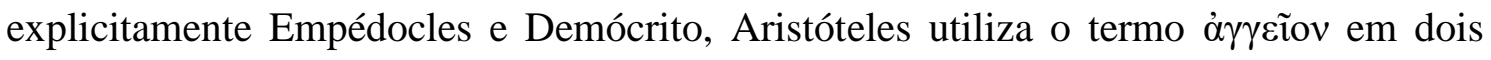
sentidos ligeiramente diferentes. Primeiro ele sugere que os elementos tanto em Empédocles quanto em Demócrito são persistentes e surgem (de modo separado) a partir da decomposição de compostos, como se os compostos fossem uma espécie de

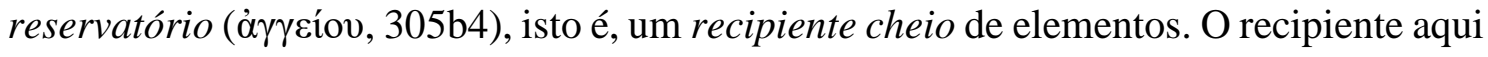
não é vazio (até porque Empédocles não admite o vazio), mas um composto que contém

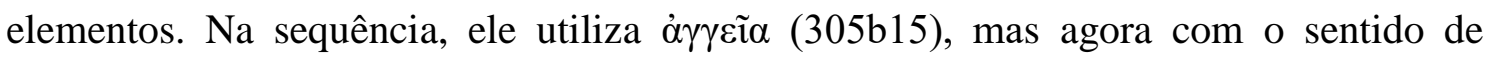
recipientes cheios de líquidos que estouram devido à vaporização dos líquidos e o consequente aumento de pressão.

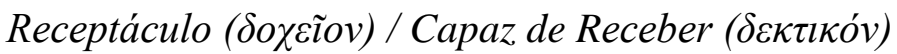

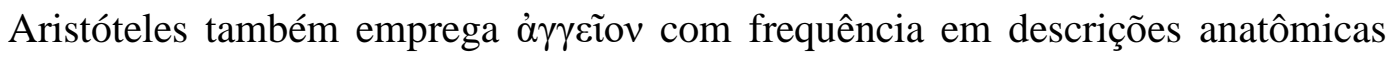
para se referir a órgãos que possuem ou funcionam como receptáculos (HA 3.20 521b6),

\footnotetext{
${ }^{8} C f$. também LM22 D25a (DK44 A27) e DK68 C6.10 ( $\neq$ DK), que descrevem vasos sanguíneos

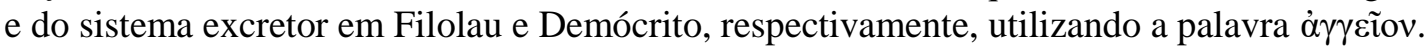


como o pulmão (GA 5.7 787b3), o ventre ( $P A 4.5$ 680b34), a mama ( $P A 4.11692 \mathrm{a} 12)$ e até mesmo vasos sanguíneos (HA 3.2 511b17). Uma característica comum a esses órgãos

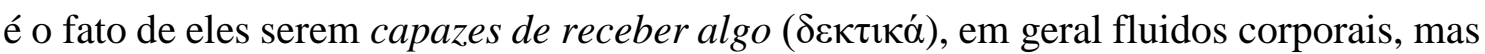

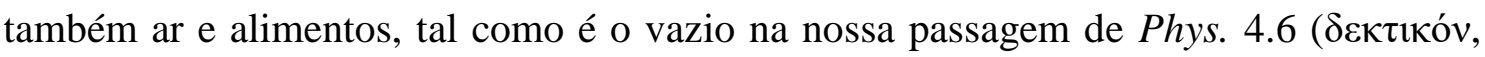
213a17).

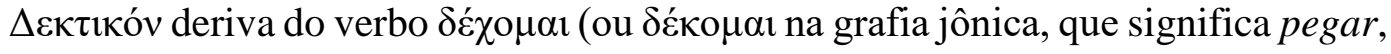
aceitar, receber; $c f$. Beekes, 2010, p. 320). Deste verbo derivam outras palavras que têm

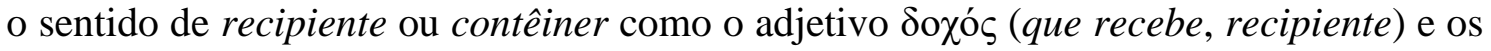

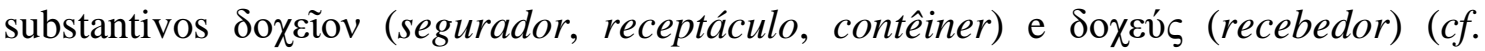
Beekes, 2010, p. 321). ${ }^{9}$

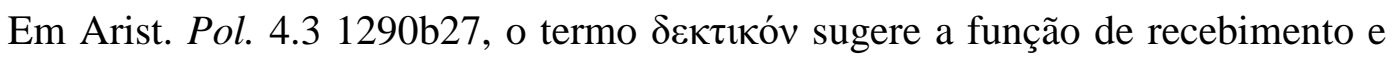
absorção de alimentos desempenhado pelo par boca e estômago. Já em Resp. 8 474b6-7, Aristóteles diz que os vasos sanguíneos $(\varphi \lambda \varepsilon \dot{\varepsilon} \beta \alpha)$ existem em função do sangue, "como

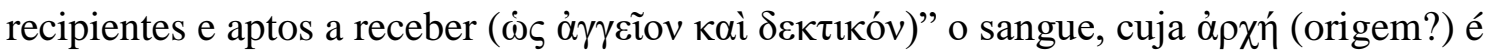
o coração (474b5-6). O que se pode depreender aqui é que os vasos sanguíneos, que

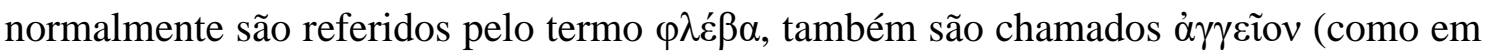
HA 3.2 511b17), porque têm como principal função receber, conter e viabilizar o transporte do sangue através do corpo, a partir do coração. Isso está de acordo com a

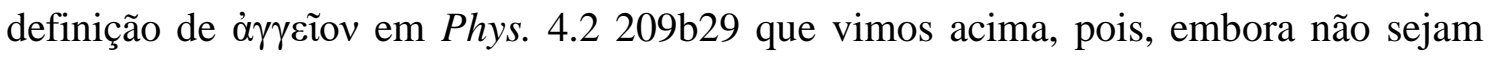
como um jarro de vinho, que uma pessoa toma e carrega consigo de um lugar para o outro,

\footnotetext{
${ }^{9}$ Algumas outras palavras derivadas de $\delta \varepsilon ́ \chi 0 \mu \alpha \imath$ que têm sentidos interessantes:

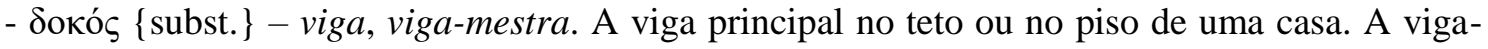
mestra "toma sobre si", isto é, recebe a cobertura (Beekes, 2010, p. 345: "which takes on [the covering]"). É como se ela recebesse por ser o fundamento, isto é, o lugar onde se assenta, toda a estrutura.

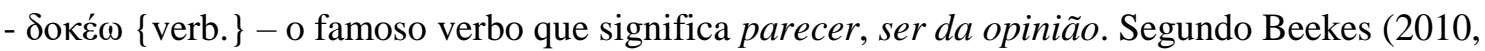

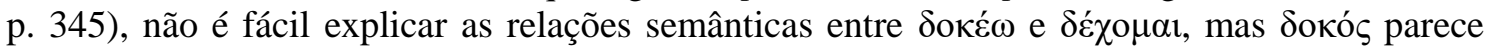
ajudar. Talvez, dizer 'o que me parece' equivalha a identificar uma "base" sobre a qual eu posso "montar" uma opinião.

- $\delta \varepsilon ́ \kappa \tau \omega \rho ~\{$ subst. - aquele que recebe. Alguém que toma algo sobre si ou sobre sua própria

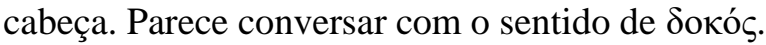

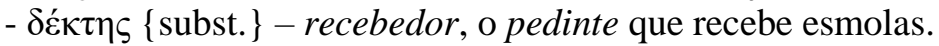

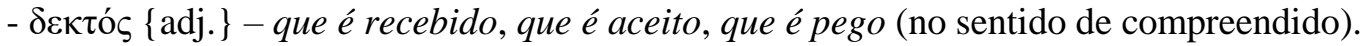

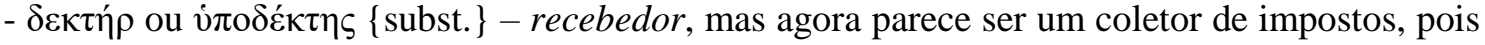
o termo é utilizado como título oficial ( $c f$. Beekes, 2010, p. $321 \&$ LSJ).

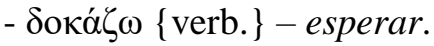

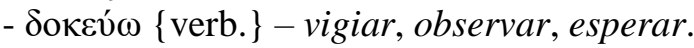

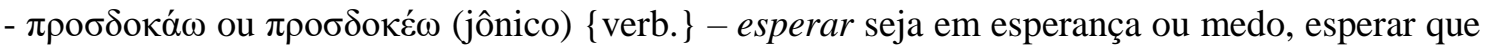
algo ou alguém chegue; pensar, supor que algo seja o caso; hesitar; procurar por algo.
} 


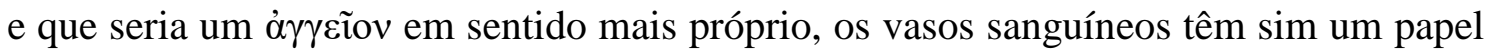
no transporte do sangue através do corpo, funcionando como vias.

Esses mesmos sentidos ocorriam em Demócrito, que, segundo o léxico de Hesíquio (LM27 D182 = DK68 B135), empregava o termo $\delta \varepsilon \xi \alpha \mu \varepsilon v \alpha i ́$ (recebedoras), também derivado de $\delta \varepsilon ́ \kappa o \mu \alpha$, para indicar "recipientes para água [ou fluidos em geral] ${ }^{10} \mathrm{e}$ as veias

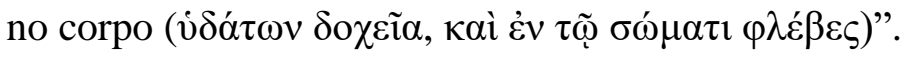

Temos ainda o caso das cinzas, que Aristóteles menciona em Phys. 4.6 e que costuma ser elencado como um dos argumentos democritianos a favor do vazio:

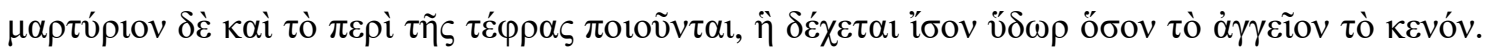
(Arist. Phys. 4.6 213b21-22 [<LM27 D39; < DK67 A19])

Eles também produzem como evidência o que se passa com a cinza, a qual recebe tanta água quanto um recipiente vazio.

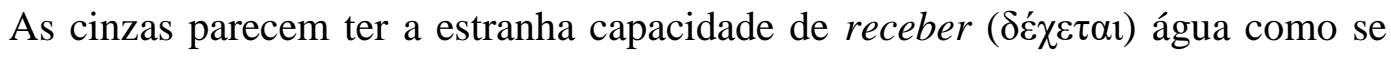

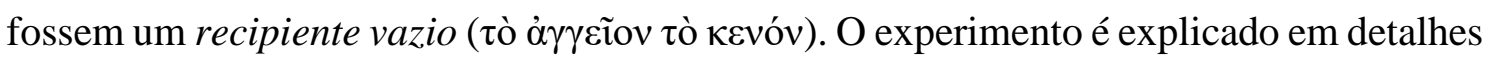
em Ps.-Arist. Probl. 25 938b14-939a9. Neste capítulo 25, o comportamento do ar é discutido em várias situações, dentre as quais aparece o problema das cinzas. Ao que parece, quando a água é derramada num recipiente cheio de cinzas ela substitui o ar nas

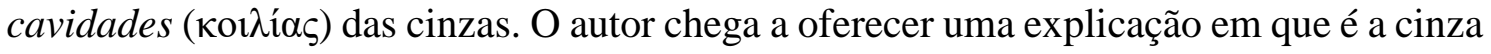
que recebe a água mesmo quando ela é misturada à água já no recipiente. O que torna a cinza semelhante a um vaso é a presença dessas cavidades por onde a água penetra, gerando efeito semelhante ao que ocorre quando ela é derramada em um recipiente vazio.

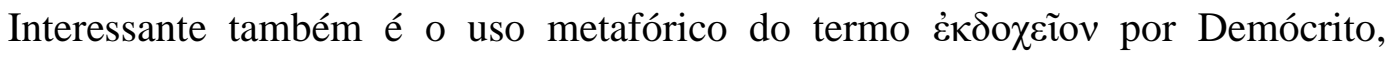
conforme reportado por Porfírio:

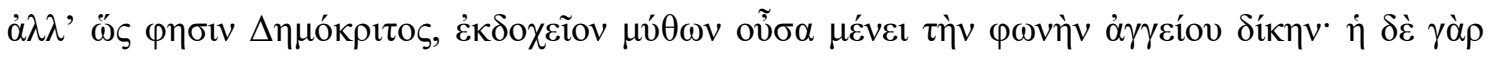

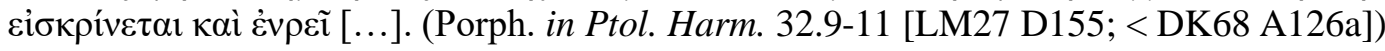

mas, como diz Demócrito, [a audição,] sendo um receptáculo de palavras, espera pelo som à maneira de um recipiente. Pois este [i.e. o som] se introduz e flui para dentro [...].

No contexto da citação (a partir de 32.6), Porfírio faz uma distinção entre o aparelho

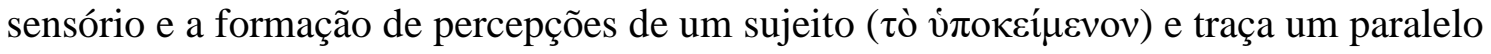

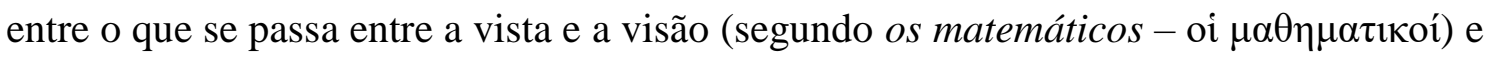
o que se passa entre o aparelho auditivo e a audição (segundo Demócrito). Ao que parece,

\footnotetext{
${ }^{10} C f$. a tradução de Laks \& Most.
} 
para Demócrito, o som penetra e flui para dentro dos ouvidos (e eventualmente para a audição onde é recebido já convertido em palavras), como um fluido que se derrama em

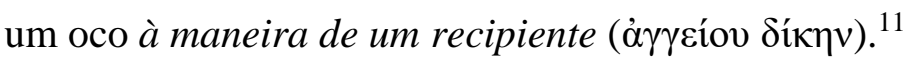

É impossível não notar o paralelismo desta passagem com Phys. 4.6 213a15-19

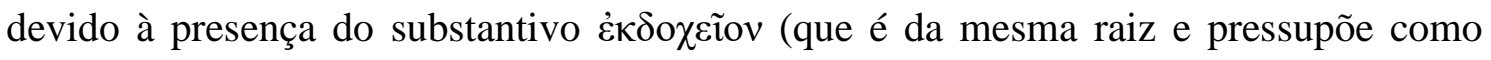

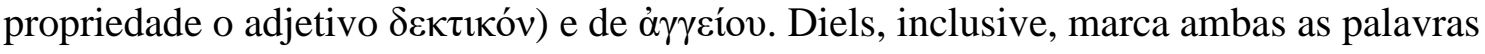

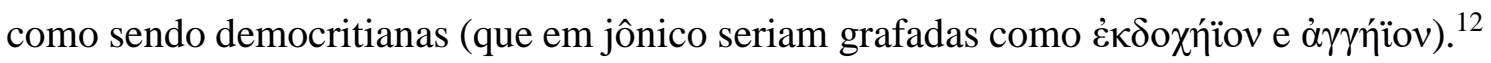
Se ele estiver certo, então, há margem para especular que Aristóteles talvez tivesse diante de si (além de outros materiais relativos a outros autores, evidentemente) a mesma passagem que Porfírio.

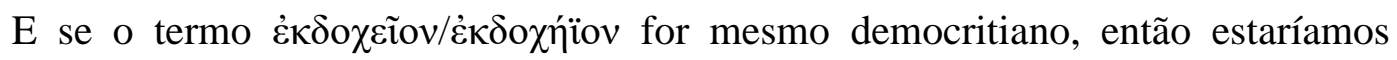
possivelmente diante de um uso metafórico da noção de receptáculo. Palavras são signos ou representações, objetos noéticos obtidos a partir de sons que atingem o aparelho sensório pelos ouvidos. O ouvido não pode ser um receptáculo de palavras, apenas de sons. Isso pode sugerir a presença no "interior" da mente de uma espécie de recipiente ou espaço noético distinto das palavras onde elas ocorrem e realizam suas funções noéticas.

Ainda neste sentido metafórico vale mencionar, por fim, um testemunho de João Lídio (Io. Lyd. Mens. 1.15 [DK44 A13; ₹ LM]) que sugere que Filolau teria chamado o número 10 - o número completo e perfeito que engloba as formas de todos os outros

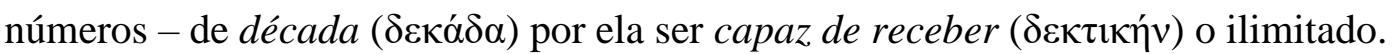

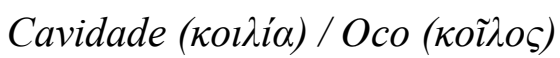

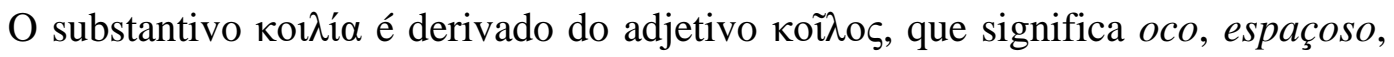
profundo, afundado, encavado, e também côncavo e, claro, vazio (cf. Beekes, 2010, p. 730). Koĩ $\mathrm{o}$ ऽ aparece em muitos contextos - cosmogônicos, físicos e fisiológicos - e, na maior parte das vezes, como característica de uma região. Em DK28 B20 (₹ LM), um fragmento atribuído a Parmênides, ${ }^{13}$ menciona-se "um caminho subterrâneo de dar

\footnotetext{
${ }^{11}$ Uma formulação quase idêntica ocorre na epístola pseudoepígrafa de Demócrito a Hipócrates (Hippoc. Epist. 23.5 [9.394 Littré; DK68 C6.5; = LM]): "E os ouvidos foram abertos [como]

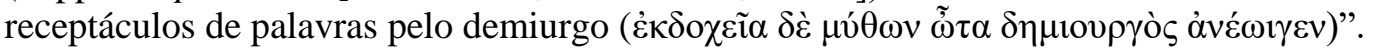

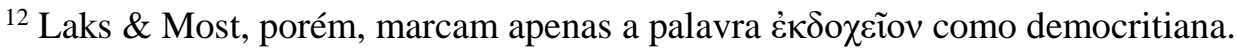

${ }^{13}$ Que Diels considera dúbio, por sinal, mas isso não vem ao caso, pois o que nos importa são os usos do termo, não tanto seus usuários, muito embora seja importante permanecermos próximos dos "pré-socráticos".
} 
calafrios, / encavado (коí $\eta$ ) e lamacento" através do qual se chega ao bosque de Afrodite. Para Anaxágoras (segundo Hipp. Ref. 1.8.5 [< LM25 D4; < DK59 A42]), a terra

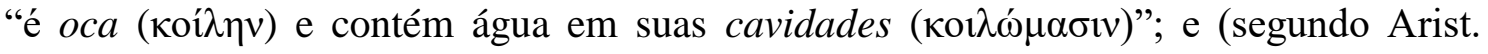
Meteor. 2.7 365a19-25 [LM25 D62a; DK59 A89]) os terremotos seriam causados por

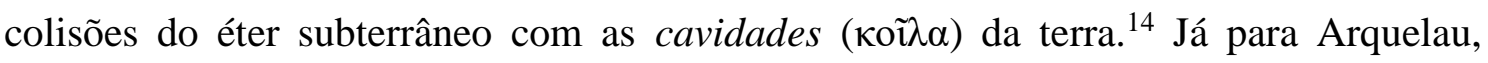
(segundo Hipp. Ref. 1.9.4 [< LM26 D2; DK60 A4]), a terra tem formato côncavo:

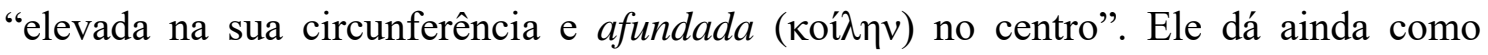

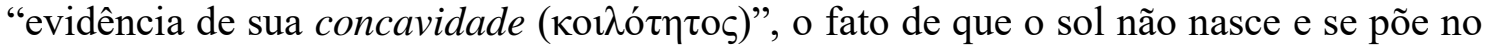
mesmo horário em todos os lugares. Além disso, (segundo Diog. Laert. 2.17 [LM26 D3;

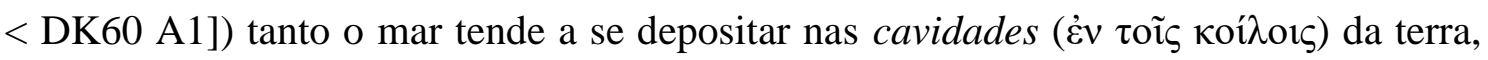
quanto (segundo Sen. Quaest. nat. 6.12.1 [DK60 A16a; $\neq \mathrm{LM}$ ]) os ventos se dirigem para uma região côncava (concava), ou em forma de fosso. Também para Diógenes de Apolônia (segundo Alex. in Meteor. 67.8-9 [<DK64 A17; f LM]), o mar é a umidade

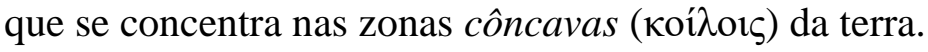

Nos testemunhos sobre Demócrito também encontramos descrições da terra sendo

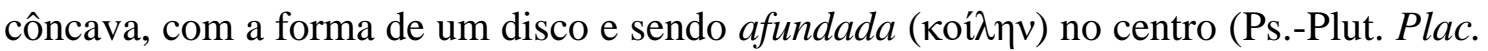
phil. 3.10.5 [= Aët. 3.10.5; DG 377; < LM27 D111; DK68 A94]). Sêneca (Quaest. nat. 6.20.1-4 [LM27 D119b; < DK68 A98]) a certa altura diz que "uma certa porção da terra é oca (concava)" e é nela que o vento penetra e causa os terremotos. Além disso, ele descreve em detalhes como a água penetra no subsolo e escava passagens por causa de seu peso e ímpeto. As descrições detalhadas de Sêneca se assemelham a uma passagem em que Pseudo-Plutarco apresenta uma cosmogonia anônima de tipo atomista (Ps.-Plut. Plac. phil. 1.4.1-4 [= Aët. 1.4.1-4; DG 289-291; DK67 A24; = LM]). ${ }^{15}$ Um trecho em

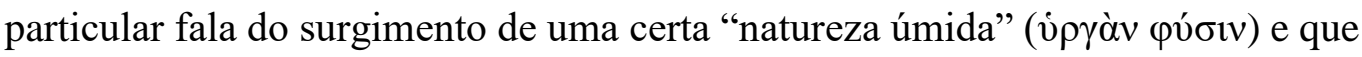

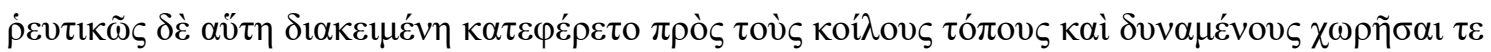

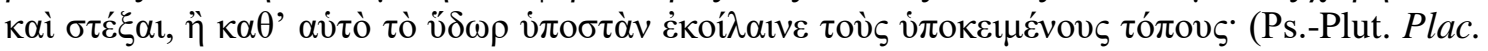
phil. 1.4.4)

esta, sendo fluidamente disposta, era conduzida para baixo para lugares cavernosos e capazes de lhe dar espaço e contê-la; ou então, era a própria água que, depositando-se, escavava os lugares que tinha por baixo.

\footnotetext{
${ }^{14}$ A explicação envolve uma parte baixa e uma parte alta (onde nós estamos) da terra. Entre essas duas partes há cavidades (pois a terra é porosa), mas esses poros ficam entupidos. Ao que parece, o éter aprisionado nas partes mais baixas se choca contra essas cavidades entupidas e gera o terremoto.

${ }^{15} \mathrm{Na}$ qual Leszl, 2009, p. 245 (WL 80.2), vê indícios de uma matriz epicurista.
} 
Neste trecho, ocorrem muitas expressões que nos interessam: lugares cavernosos

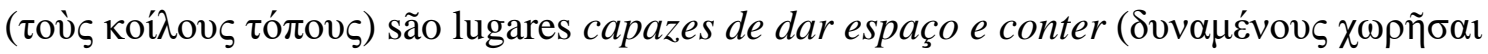

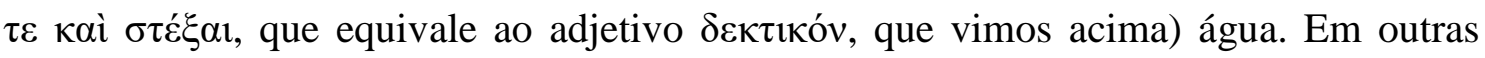
palavras, funcionam como bons recipientes.

Ainda neste sentido mais geológico, temos um testemunho de Aristóteles (Meteor. 2.7 365b1-6 [LM27 D119a; DK68 A97]) em que, mais uma vez (como em Anaxágoras, acima), cavidades subterrâneas têm papel na explicação de terremotos. Segundo

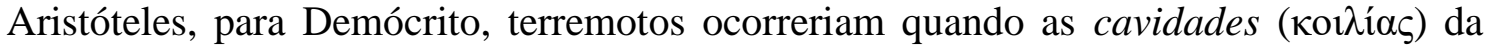
terra ficam completamente cheias de água, fazendo com que a terra se mova. E quando a

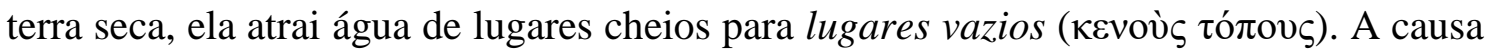
dos terremotos seriam esses movimentos da água dentro da terra, tanto quando ela fica cheia demais, como também quando ela seca, talvez, abruptamente, levando ao movimento contrário.

O substantivo кoı $\lambda i ́ \alpha$, por sinal, que aparece nesta passagem dos Meteorológicos, é utilizado principalmente para designar cavidades corporais, em particular o tórax e o abdômen. Em muitos contextos pode ser traduzido por ventre, barriga ou mesmo intestino. A partir deste uso principal, кoı $\lambda i ́ \alpha$ acaba designando qualquer tipo de cavidade ou oco. Koĩ houvesse uma tendência de fluidos (como água, ar e éter) se deslocarem e ocuparem lugares ocos. Isso ocorre em especial no subsolo, mas não exclusivamente aí, pois também no corpo humano há essa tendência.

Aristóteles, por exemplo, utiliza o termo кoı $\lambda i ́ \alpha$ com o sentido de ventre (ou abdômen) em seu sumário da teoria de Diógenes de Apolônia sobre o sangue e o aparelho circulatório em HA 3.2 511b31-513b11 (LM28 D27 = DK64 B6), que alguns consideram ser uma citação direta de Diógenes. ${ }^{16}$ Também Teofrasto, descrevendo os efeitos do sabor doce dentro do aparelho digestivo segundo Demócrito, diz que ele umidifica o alimento

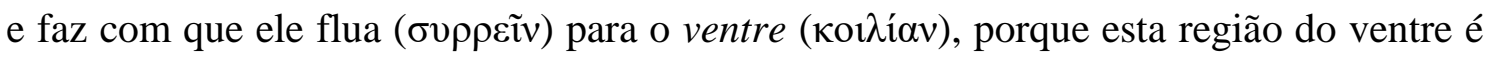

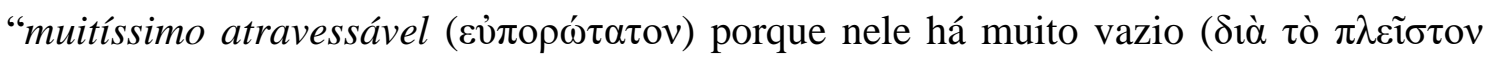

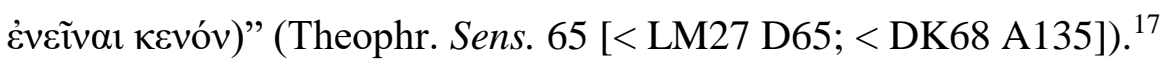

\footnotetext{
${ }^{16}$ Ver também Theophr. Sens. 44 (LM28 D44; < DK64 A 19) e Ps.-Plut. Plac. phil. 4.5 .7 (= Aët.

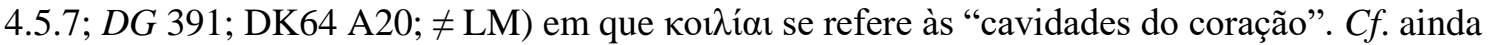
Theodor. Cur. 5.22 (DK31 A97; f LM), que também fala de "cavidades do coração", e o termo empedocleano $\beta \alpha v \beta \omega ́$, que Hesíquio traduz por кoı $\lambda i ́ \alpha$ (LM22 D160; DK31 B153).

${ }^{17} \mathrm{Na}$ sequência (Sens. 66), Teofrasto diz que o sabor adstringente ( $\left.\sigma \tau \rho v \varphi v o ́ v\right)$ tem inclusive o

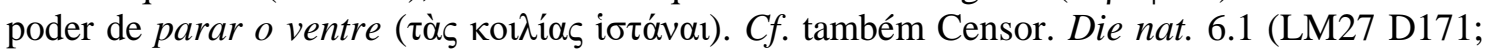


Teofrasto nos relata ainda que Alcméon diz que a audição ocorre nos ouvidos porque há um vazio dentro deles (Theophr. Sens. 25 [<LM23 D12a; < DK24 A5]). E que é neste oco (коí $\omega$ ) que se produz o som. Esta provavelmente é a fonte de uma passagem muito semelhante de Estobeu (Ecl. 1.53.2 [= Aët. 4.16.2; DG 406; LM23 D12b; < DK24 A6]), onde lemos que, para Alcméon, “todas as coisas ocas (кої $\alpha$ ) ressoam”. Por sinal, a passagem equivalente em Pseudo-Plutarco (Plac. phil. 4.16.2) é idêntica, exceto

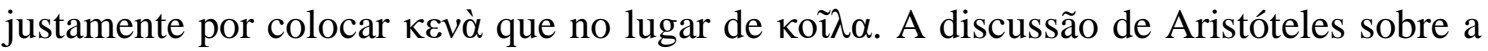
audição e a formação de sons em An. 2.8 parece dialogar com essa concepção aqui

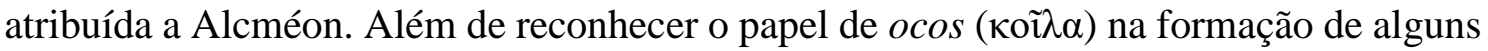
tipos de sons, especialmente os que reverberam (419b14-18), a certa altura ele diz:

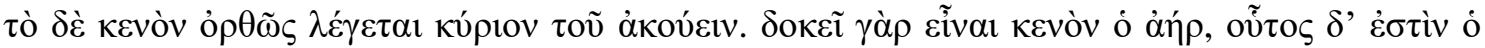

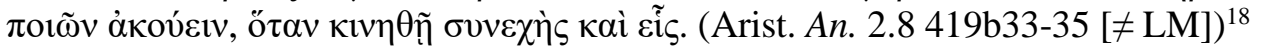

Se diz corretamente que o vazio é responsável pelo ouvir. Pois o ar parece ser vazio e este é o produtor do ouvir, quando é movido [de modo] contínuo e uno. ${ }^{19}$

E, mais adiante:

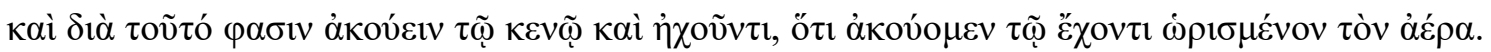
(Arist. An. 2.8 420a18-19 [ $\neq \mathrm{LM}$; $\neq \mathrm{DK}]$ )

Por causa disso, dizem que o ouvir se dá por meio do vazio e do que ecoa, porque ouvimos por meio do ar limitado que retemos [i.e. no interior dos ouvidos].

A explicação de Aristóteles para como se dá o som e a audição neste capítulo é bastante precisa. Ele não só tem clareza de que o som se propaga por meio do ar, como deixa implícito que não haveria som no vácuo.

Note como essa discussão de Aristóteles e os dois testemunhos sobre Alcméon acima têm paralelos com a passagem em que Porfírio (in Ptol. Harm. 32.9-11 [LM27

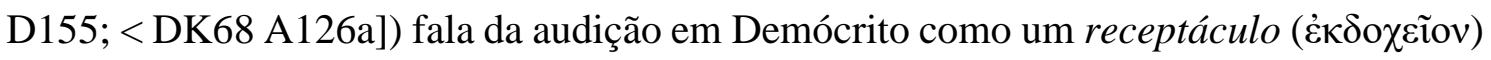

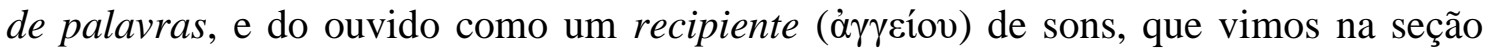

DK68 A145), que diz que as duas primeiras partes que se formam no embrião são o ventre (alvum) e a cabeça, justamente porque essas duas partes contêm mais vazio (plurumum habent ex inani). (Agora, por que isso ocorre já é um mistério.)

${ }^{18}$ Diels menciona esta passagem (mas não a lista) como referência em DK24 A6. Ele também menciona Hippoc. De carn. 15 (8.603 Littré), onde o autor explica que a audição depende de um

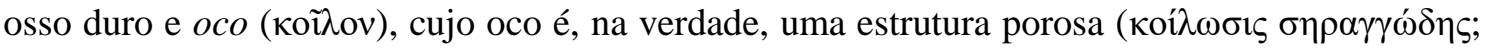
lit. entalhe poroso).

${ }^{19}$ Isto é, como uma massa una e contínua de ar, e não em seu movimento aleatório normal. É assim que Aristóteles qualifica o ar que transmite o som em An. 2.8. 
anterior. Teofrasto inclusive dá notícia de que a explicação de Demócrito sobre a audição era relativamente semelhante à de outros filósofos: ele entendia que o som se propagava por meio do ar e que era pela passagem do ar pelas cavidades do ouvido que o som podia ser capturado pela percepção auditiva (Theophr. Sens. 55 [< LM27 D157; < DK68 A135]). ${ }^{20}$ Sendo assim, também é razoável supor que mesmo para Demócrito não haveria propagação de som numa câmara de vácuo. Pois seria necessário que o vazio em qualquer ambiente estivesse ocupado com ar ou outro meio tênue para que o som se propagasse. Isso pode implicar, por fim, que também Demócrito não teria problemas em utilizar o

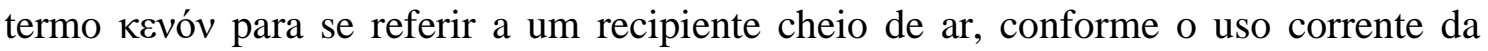
linguagem. Assim, não haveria problema em se referir a uma caverna vazia como sendo um lugar propício para a ocorrência do fenômeno do eco. Uma caverna onde ocorre o eco, evidentemente, não é uma caverna completamente vazia, mas apenas sem outros objetos que possam atrapalhar a propagação livre dos fluxos particulares de ar que transportam determinado som. O eco, aliás, faz parte da descrição de Teofrasto sobre o mecanismo da audição em Alcméon mencionada acima.

Há ainda um último tipo de uso em que коĩ físico-cosmológico. Tudo começa em uma passagem um pouco obscura de Sobre a geração dos animais (GA 2.8 747a34-b3 [LM22 D185; < DK31 B92]) em que Aristóteles diz que Empédocles, falando da esterilidade da mula, dizia que o problema estaria na mistura das sementes, quando as partes ocas ( $\tau \hat{\alpha}$ коĩ $\lambda \alpha$ ) de uma se conectariam às partes

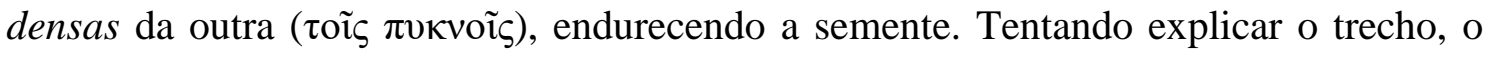
autor do comentário a GA atribuído a Filopono (Ps.-Philop. in GA 123.13-16 [< DK31 A87; $\neq \mathrm{LM}]$ ), sugere que os "entes sublunares" de Empédocles são compostos de passagens e partes sólidas ( $\pi$ opov̀ $\varsigma \alpha \grave{~ v \alpha \sigma \tau \alpha ́) ~ e ~ q u e ~ e s s a s ~ p a s s a g e n s ~ c o r r e s p o n d e m ~ a ̀ s ~}$

${ }^{20}$ É interessante comparar a descrição de Teofrasto sobre a audição em Demócrito (Theophr. Sens. 55-56 [LM27 D157; < DK68 A135]) com a que aparece no capítulo sobre audição do tratado hipocrático Sobre as carnes (Hippoc. Carn. 15 [8.603 Littré] [₹ LM]). Ambas as explicações destacam a necessidade de que os canais sejam secos, mas enquanto no tratado hipocrático o osso, embora seja duro, é oco e poroso, em Teofrasto apenas se diz que ossos envolvidos no processo devem ser "densos" ( $\pi v \kappa v \alpha ́)$. Além disso, o autor do tratado hipocrático rechaça especificamente

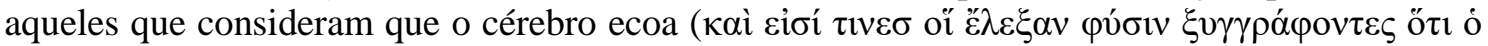

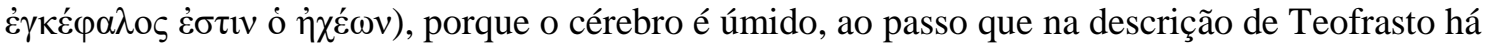

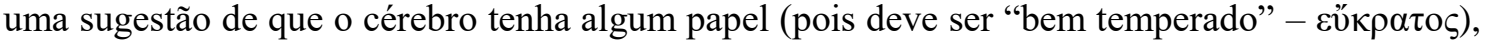
embora não fique claro exatamente que papel é esse. Ressalva-se, porém, que o que envolve o

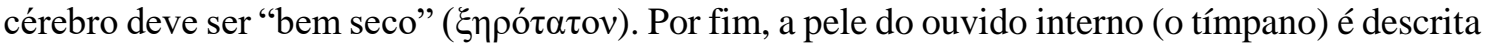

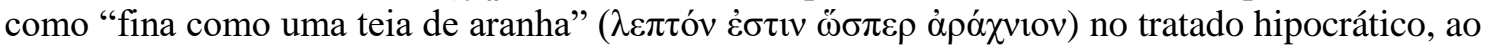

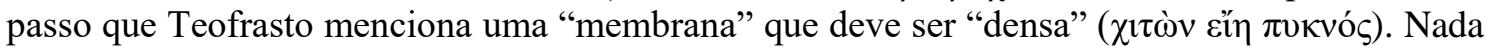
impede, porém, que a membrana democritiana seja fina e densa. 
partes ocas de $G A 2.8$, ao passo que as partes sólidas correspondem às partes densas. É interessante ainda como o autor do comentário acaba atribuindo a Empédocles um esquema de princípios muito semelhante ao de Demócrito, com elementos sólidos e

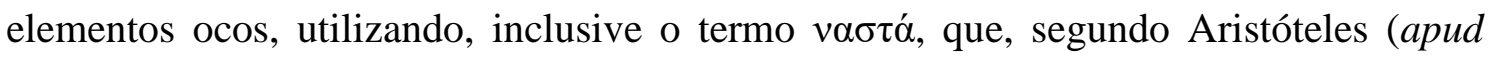
Simpl. in Cael. 295.5 [< LM27 D29; < DK68 A37]), era utilizado por Demócrito para caracterizar os átomos. ${ }^{21}$

O Filopono autêntico de fato reconhece uma aproximação entre Empédocles e Demócrito a partir da leitura de Arist. GC 1.8 (cf. Philop. in GC 160.3-11 [<WL 21.7; > DK31 A87]). Mais adiante em seu comentário, porém, ele qualifica melhor a comparação e diz que as passagens de Empédocles não são realmente vazias, mas contêm uma substância muito sutil (Philop. in GC 178.2-5 [DK31 A87; \# LM]).

\section{O Xáos de Hesíodo}

Outro trecho interessante é uma interpretação de Hesíodo proposta no tratado peripatético Sobre Melisso:

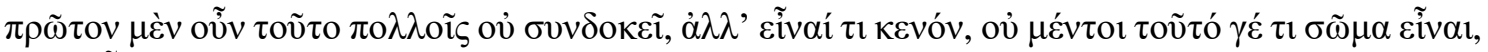

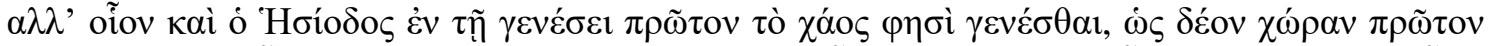

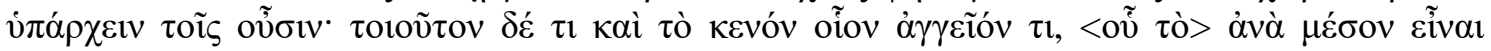
$\zeta \eta \tau o \tilde{v} \mu \varepsilon v$. (Ps.-Arist. $M X G 2.26$ 976b14-18 [<DK30 A5])

Em primeiro lugar nem todos concordam com isso [i.e. que, por não haver vazio, tudo se move trocando de lugar], mas [alguns pensam] haver algo vazio, sem que isso seja um corpo, mas tal como também Hesíodo, na geração [do mundo], diz surgir primeiro o Caos, como se fosse preciso existir primeiro um espaço para as coisas que são. E o vazio é algo deste tipo, como um recipiente, cujo meio buscamos (?). ${ }^{22}$

$\mathrm{O}$ autor do tratado sugere que o Xáos (abismo, lacuna, separação, abertura) de Hesíodo deve ser interpretado como uma espécie de espaço primordial ( $\chi \omega ́ \rho \alpha \nu \pi \rho \tilde{\omega} \tau o v$ ) no qual surgirão as demais coisas - inicialmente Terra, como a sede dos deuses imortais ${ }^{23}$

\footnotetext{
${ }^{21}$ Segundo esse mesmo testemunho, aliás, Demócrito teria indicado que uma das formas possíveis dos átomos seria a côncava (коі̃ $\alpha$ ) (cf. Simpl. in Cael. 295.17).

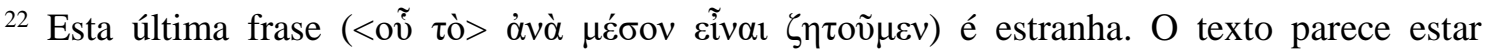

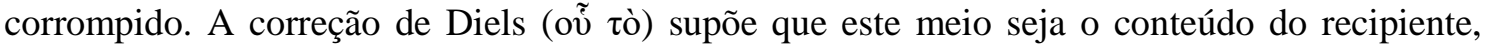
sugerindo, ao que parece, que se trata das coisas que são e que estão dentro dele.

${ }^{23}$ Esta ideia da terra como sede concorda com a cosmologia egípcia descrita por Hecateu, que vimos acima.
} 
e, abaixo dela, nas suas profundezas, o Tártaro (cf. Hes. Th. 116-119 [LM2 T11.116-119;

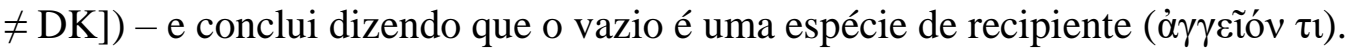

Esse trecho de $M X G$ está claramente retomando uma passagem do início da discussão de Aristóteles sobre o lugar em Phys. 4.1, onde ele cita Hesíodo. O capítulo começa com Aristóteles listando uma série de motivos pelos quais a investigação sobre o lugar é importante e, em especial, indícios de que exista algo como o lugar e de que ele tem papel destacado no chamado movimento local. A certa altura, ele acrescenta como um desses indícios a noção de vazio e esta é também a primeira ocasião em que ele sugere que o vazio deve ser entendido como um lugar privado corpo:

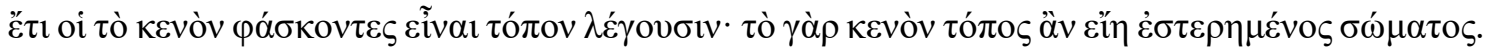
(Arist. Phys. $4.1208 \mathrm{~b} 25-27$ [WL 30.4; \# DK])

Além disso, aqueles que alegam existir o vazio falam de lugar, pois o vazio seria um lugar privado de corpo.

Na sequência ele menciona e cita Hesíodo:

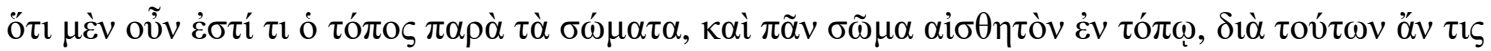

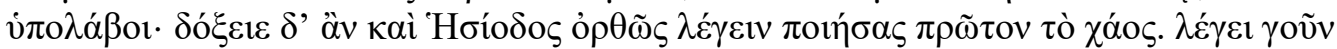

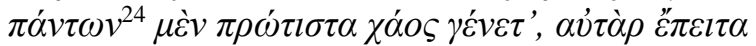

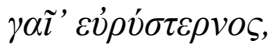

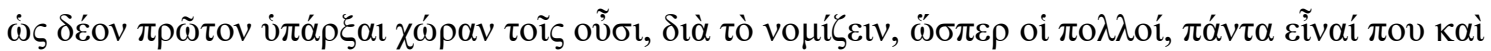

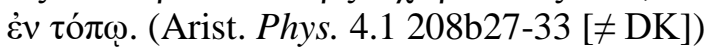

Por causa dessas coisas, pode-se supor que o lugar seja algo além dos corpos e que todo corpo perceptível seja em um lugar. E também Hesíodo pareceria falar corretamente quando faz do Caos o primeiro. Pois ele diz que

De todas as coisas a primeiríssima a surgir foi o Caos e, em seguida,

A Terra de amplos seios,

como se devesse existir primeiro um espaço para as coisas que são, porque pensava, tal como a maioria, que todas as coisas são em um onde e em um lugar.

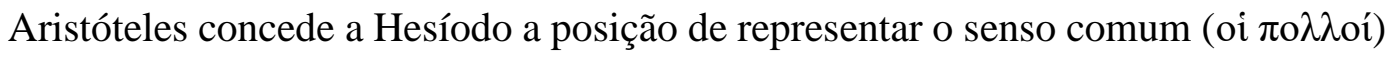
com uma ideia de que é preciso haver um espaço ( $\chi \omega ́ \rho \alpha v)$, que depois ele designará como sendo um onde ( $\pi \mathrm{ov})$ em que as coisas possam existir, ou seja, um lugar ( $\tau$ ó $\pi \omega)$. Ele se mostra ainda maravilhado (ironicamente, claro, pois ele discorda desta concepção) com a potência deste lugar primordial:

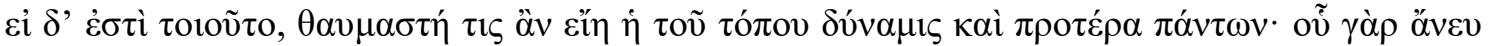

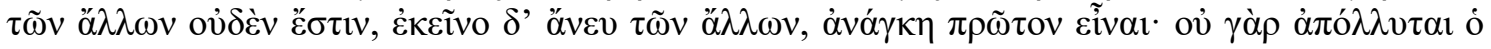

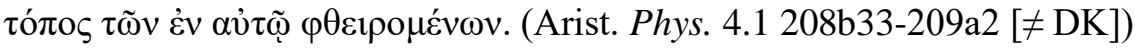

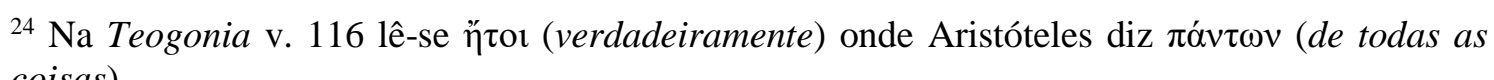
coisas). 
Mas se é assim, a potência do lugar seria espantosa e anterior a todas as coisas: pois aquilo sem o que nenhuma das outras coisas existe, mas que existe sem as outras coisas, deve ser necessariamente a primeira. Pois o lugar não é destruído quando as coisas nele são desfeitas.

A concessão a Hesíodo prossegue, portanto, para a ideia de que a única razão plausível para colocar Caos como o primeiro dos deuses é a necessidade de uma espécie de sede para as demais coisas existirem, assim como Terra será a "sede firme" dos deuses produzidos em seu seio ( $c f$. Hes. Th. 117-118). Ao mesmo tempo, seu caráter imortal e imperecível, concede ao Caos o estatuto de princípio cosmogônico, que se tornará cosmológico na sua versão leucipiana.

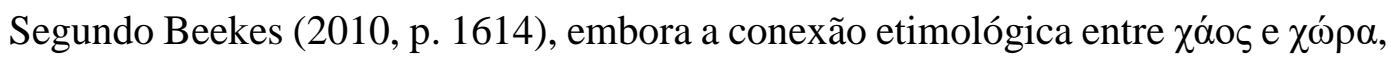
estabelecida desde a antiguidade por Aristóteles, tenha sido eventualmente questionada

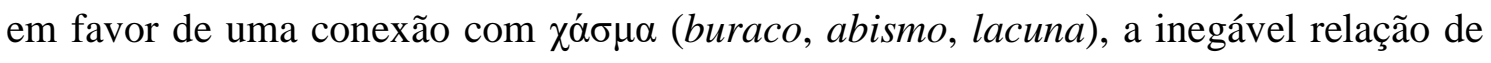

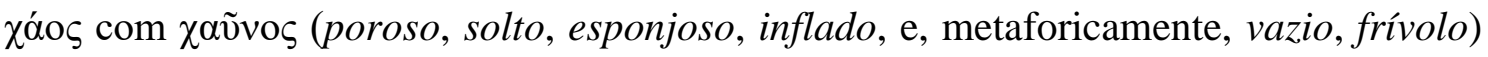
sugere que os dois sentidos convergem. ${ }^{25}$ Em outras palavras, é como se $\chi \alpha ́ o \zeta$ fosse capaz de unir numa única palavra tanto um sentido figura, isto é, o contorno que demarca um grande abismo, quanto um sentido fundo, ou seja, o que há no interior deste grande abismo: um imenso espaço vazio.

Nas Aves de Aristófanes também encontramos uma breve teogonia que envolve Caos (v. 693-702). Nela, diferentemente do que se passa na Teogonia de Hesíodo, Caos é listado como uma de quatro divindades primordiais, junto com Noite, Érebo e Tártaro. Neste relato, nos é dito que Caos tem duas características: ser escuro e ser alado como Eros, que vem para uni-lo ao Tártaro. Há ainda outra ocorrência da palavra em Av. 1218, mas ali ela tem o sentido trivial de região, país, espaço, exceto por um pequeno detalhe: é que, por se tratar de uma cidade nos céus, não se pode falar em terra, de modo que isso talvez sirva para realçar o sentido espacial de $\chi \alpha ́ o s$.

Já nas Nuvens, Aristófanes parece contar Caos entre divindades “aéreas” junto com as próprias Nuvens, o Ar, o Éter e a Respiração, além da Língua, que não é propriamente aérea, mas talvez compartilhe com as demais divindades invocadas por Sócrates de uma certa sutileza (Ar. Nub. 264-266, 424, 627), isso sem falar que ela é a origem das palavras que se propagam como som através do ar. O sentido irônico talvez seja justamente o da falta de substância desses deuses e deusas. O Sócrates das Nuvens passa boa parte do seu

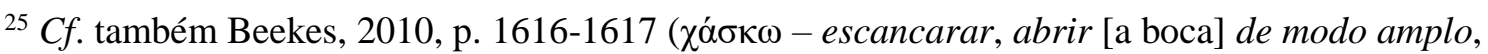

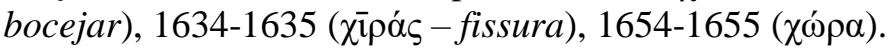


tempo suspenso numa cesta para ficar mais próximo do céu ( $c f$. v. 216-217) e essas divindades são patronas dos pensadores e dos ociosos (v. 316). Embora figure entre tais divindades "aéreas", Caos não deve ser confundido com o Ar, pois este, junto com a Respiração, já estão listados como entidades distintas. Cabe, portanto (e assim parecem entender tanto LSJ quanto Beekes, 2010, p. 1614), a hipótese de que Caos corresponda, também para Aristófanes, a uma espécie de nada, um espaço vazio (e que talvez inspire os que não fazem nada ou não têm nada na cabeça).

Por fim, registremos ainda mais duas passagens. A primeira é de uma ode do poeta Baquílides (séc. V aec) que, a certa altura, descreve que o voo da águia de Zeus, que bate

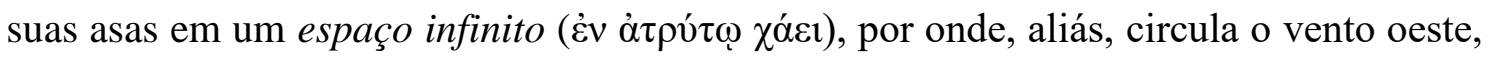
no qual ela parece surfar (Bacchyl. 5.26-30). Vale ainda classificar o infinito sugerido por

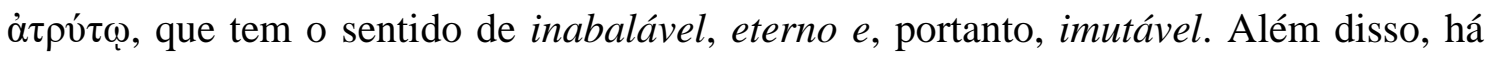
aqui, mais uma vez, uma aparente relação com o ar, pois o ar é o meio por onde a águia de Zeus se move, mas, de novo, não se trata de uma identificação entre $\chi \alpha$ ó e ar, mas

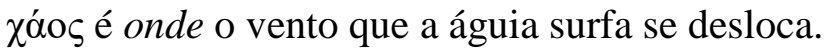

A segunda passagem é um testemunho de Aeliano sobre a embriologia de Demócrito (Ael. Nat. anim. 12.17 [LM27 D176; DK68 A152]) que diz que os embriões têm mais facilidade de vingarem e nascerem no Sul (onde é mais quente), porque o calor do vento sul torna mais porosos ( $\chi \alpha v v o \tilde{\sigma} \sigma \alpha \imath$ ) e relaxados os corpos das fêmeas grávidas. Esse estado relaxado resultante da porosidade, por sua vez, facilita a movimentação $(\pi \lambda \alpha v \tilde{\alpha} \sigma \theta \alpha \imath)$ do embrião pelo corpo e eventualmente o seu nascimento.

\section{X⿳́㇒ $\rho$ e seus Derivados}

Xópa é um termo curioso. Embora fosse extremamente comum e seja utilizado até hoje no grego moderno para se referir a coisas banais como território, país, região, espaço, lugar, o centro de um vilarejo etc., o que indica que o seu uso dificilmente geraria dificuldades de compreensão para um falante normal da língua, na filosofia, ao que tudo indica, por causa de sua aparição especial no Timeu de Platão, $\chi \omega ́ \rho \alpha$ parece ter se convertido de algo óbvio e de fácil apreensão para um conceito fugidio e complexo, ao menos entre nós modernos.

Digo 'entre nós modernos' porque talvez esta celeuma ainda não estivesse completamente colocada à época em que Aristóteles escreveu as passagens da Física com que estamos lidando (e aquelas em que a $\chi \omega ́ p \alpha$ platônica e mencionada). Não quero 
insinuar com isso um juízo sobre a interpretação de Aristóteles da $\chi \omega ́ \rho \alpha$ platônica, apenas que, talvez, uma boa forma de entender o que Aristóteles está dizendo sobre a $\chi \omega ́ \rho \alpha$ no contexto da discussão sobre lugar e vazio na Física (e a despeito do que Platão possa ter querido dizer) é pensar que ele lê o termo da maneira mais trivial possível, colocando entre parêntesis a questão espinhosa da $\chi \omega ́ \rho \alpha$ platônica.

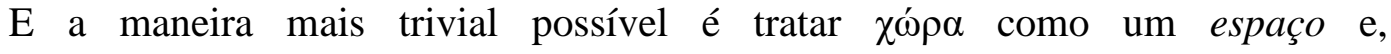
consequentemente um tipo de lugar, tal como ele sugere no excurso sobre o Caos de Hesíodo. É justamente isso que ele diz na passagem abaixo:

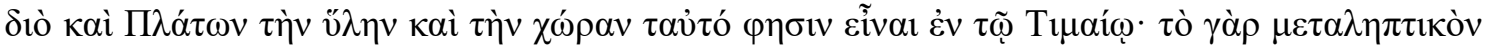

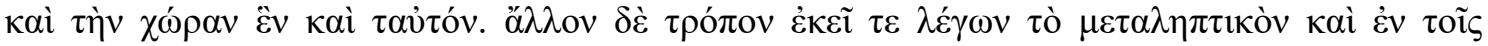

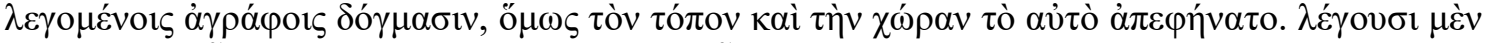

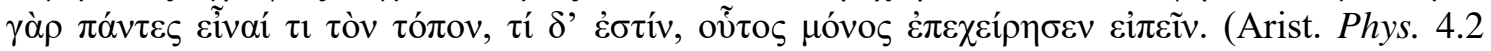
209b11-17)

É por isso [i.e., porque ao se subtrair a forma, o que resta é a matéria] que também Platão diz no Timeu que matéria e espaço são a mesma coisa. Pois "o participativo" 26 e o espaço são um e o mesmo. E embora ele tenha falado do participativo de outro modo lá nas chamadas "doutrinas não escritas", ainda assim ele declarou que lugar e espaço são o mesmo. Pois todos dizem que o lugar é alguma coisa, mas somente ele tentou dizer o que ele é.

Ora, se matéria e espaço ( $\chi \omega ́ \rho \alpha)$ forem a mesma coisa e essa coisa é o participativo ( $\mu \varepsilon \tau \alpha \lambda \eta \pi \tau$ เóv), isso pode sugerir que Aristóteles esteja entendendo que o mecanismo de participação pela mescla das formas com a $\chi \omega ́ \rho \alpha$ seja um modo de instanciar as formas que são objetos noéticos - no mundo físico. Basta que ele esteja entendendo a $\chi \omega ́ \rho \alpha$ como uma espécie de lugar primordial, tal como o Caos de Hesíodo, ou seja, compreendendo que todas as coisas concretas que são no mundo o são em algum lugar e que o modo pelo qual essas coisas vêm a ser no mundo envolve, de algum modo, a instanciação física das formas eternas e imortais. Pois no mundo não há forma separada ( $\chi \omega \rho \iota \sigma \tau o ́ \varsigma)$ da matéria (Arist. Phys. 4.2 209b30-31).

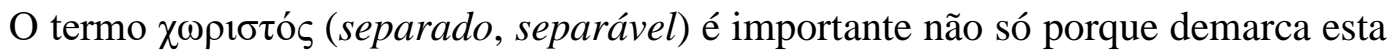
característica fundamental da relação entre forma e matéria (e, de quebra, demonstra nesta mesma passagem porque o lugar não pode ser uma forma), mas por ser ele mesmo um derivado de $\chi \omega ́ \rho \alpha$. Se $\chi \omega ́ \rho \alpha$ pode ser entendida como um espaço, então ser separado deve designar algo que não está no mesmo espaço que outra ou outras coisas. E ser separável deve designar a possibilidade de algo deixar um certo espaço compartilhado.

\footnotetext{
${ }^{26}$ Esta é a tradução sugerida por Reeve (2018) para $\mu \varepsilon \tau \alpha \lambda \eta \pi \tau ı \kappa o ́ v$, aquilo que é capaz de participar da forma.
} 
O problema, porém, em torno da $\chi \omega ́ \rho \alpha$ platônica não parece ser o do eventual lugar onde as formas existiriam independentemente das coisas, mas antes o modo pelo qual as formas seriam capazes de se instanciar no mundo sem uma matéria, já que um suposto espaço (subentende-se vazio) não pode ser a matéria das coisas, pois lhe faltaria estofo, e nem a forma seria capaz de atuar como causa material. Em outras palavras, a acusação que Aristóteles poderia estar fazendo a Platão seria a de uma hipervalorização da forma ao ponto de ela ser responsável, de algum modo, até mesmo pela matéria das coisas (no caso o grande e o pequeno; $c f$., por exemplo, Arist. Metaph. A.6 987b18-22), já que isso não poderia ser extraído da $\chi \omega ́ \rho \alpha$. Ou seja, se há $\chi \omega ́ \rho \alpha$ e formas, então é preciso haver ainda uma terceira coisa, matéria.

Voltando aos "pré-socráticos", a maior parte das diversas ocorrências de $\chi \omega ́ \rho \alpha$ e seus derivados em testemunhos e fragmentos têm os sentidos triviais de sempre, como, por exemplo, o de país ou região onde vive uma determinada pessoa que desenvolve uma doença num testemunho de Pseudo-Plutarco sobre Alcméon (Ps.-Plut. Plac. phil. 5.30.1 [= Aët. 5.30.1; DG 442; LM23 D30; DK24 B4; cf. Stob. Flor. 4.37.2]) ou dois versos de

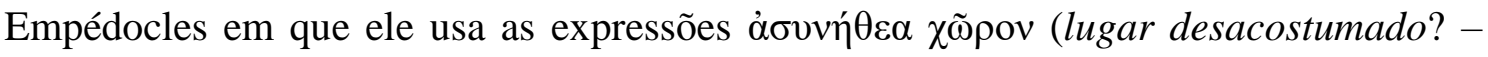

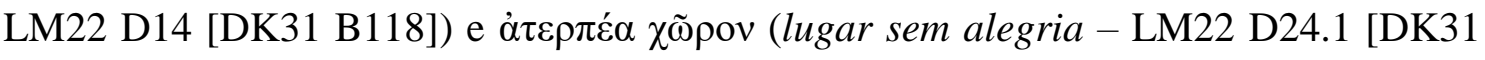
B121.1]). Temos ainda um testemunho de Estobeu sobre a formação de relâmpagos, raios, trovões e tempestades em Demócrito (Stob. Ecl. 1.29.1 [= Aët. 3.3.11; DG 369; < LM27 D117; DK68 A93]), onde se diz que, na formação do relâmpago, sementes de fogo

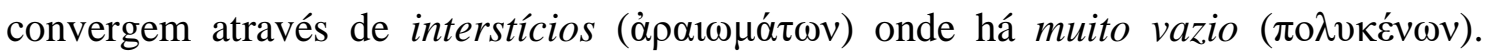
Tempestades com raios ocorrem quando agregados de fogo contendo muito vazio se

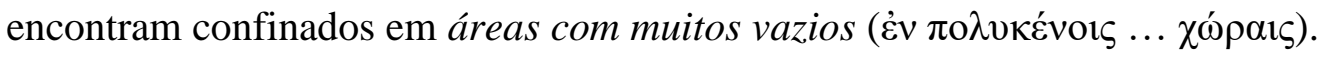

Um verbo derivado de $\chi \omega ́ \rho \alpha$ importante para a discussão do vazio é $\chi \omega \rho \varepsilon i ̃ v, ~ q u e$ significa dar lugar para outra coisa, ceder espaço, retirar, sair, ou mesmo mover-se, viajar, sempre preservando a ideia de que uma coisa que se move se move de um lugar para outro ou então se move em um espaço. Um pouco dessa ideia parece estar presente quando, em Phys. 4.1 208b6-8, Aristóteles, falando ainda sobre a noção de lugar segundo o senso comum, fala de $\tau$ ó que e para que) do movimento em que uma porção de água substitui o ar que estava em um recipiente.

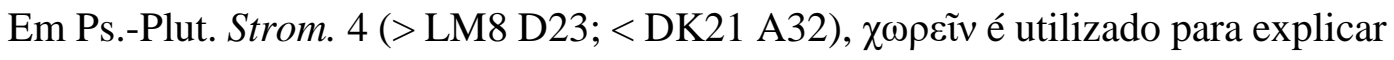
que a terra que se deposita continuamente no rio eventualmente vai ( $\chi \omega \rho \varepsilon \tilde{v} v)$ para o mar. Ou seja, ela deixa um lugar e vai para outro. O verbo também ocorre numa passagem do 
Crátilo (402a [LM9 D65c; < DK22 A6]) de Platão em que Sócrates atribui a Heráclito o dito $\pi \alpha ́ v \tau \alpha \chi \omega \rho \varepsilon \tilde{i}$, normalmente traduzido por "tudo flui" ( $c f$. Diels e Laks \& Most, por exemplo), o que é curioso, pois não se trata do verbo $\rho \varepsilon \tilde{\imath}$, que sugeriria que tudo escorre como um fluido, mas $\chi \omega \rho \varepsilon \tilde{i}$, que significa mais propriamente dá lugar a outra coisa e se

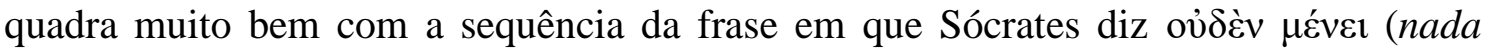
permanece). É provável que os tradutores sejam levados a atribuir o sentido de fluir para $\chi \omega \rho \varepsilon \tilde{i}$ por causa da associação que Sócrates faz logo em seguida com o famoso fragmento

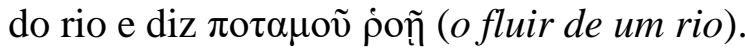

Mas o trecho mais interessante sem dúvida é do fragmento em que Melisso nega a existência do vazio:

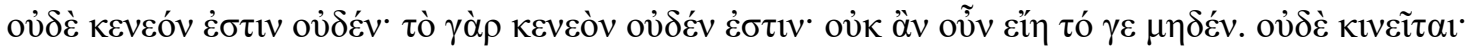

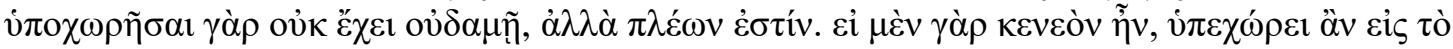

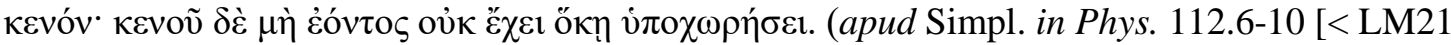
D10; < DK30 B7])

Nem há nenhum vazio. Pois o vazio é nada. Então, o que é nada não poderia ser. Nem [o-que-é] se move. Pois não tem para onde retirar-se, posto que é cheio. Se, pois, então, o vazio fosse, [oque-é-cheio] se retiraria para o vazio. Mas o vazio não sendo, [o-que-é-cheio] não tem para onde retirar-se.

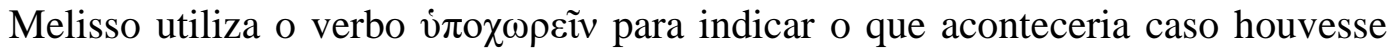
vazio. Se houvesse vazio, o-que-é acabaria movendo-se para lá - um lugar, portanto, porque haveria lugar para ele. Alguém poderia dizer "subentende-se, então, que o vazio não é cheio", mas isso não precisa estar subentendido, pois obviamente o vazio não é cheio, pois cheio e vazio são contrários. Melisso prossegue:

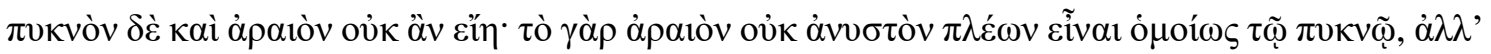

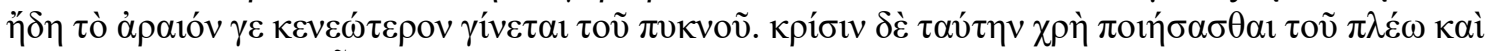

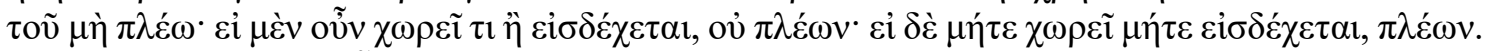

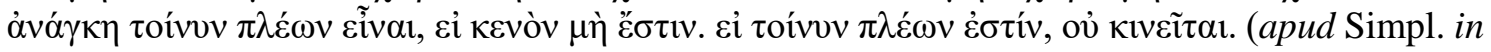
Phys. 112.10-15 [<LM21 D10; < DK30 B7])

E [o-que-é] não seria denso ou raro. Pois não é possível que o raro seja cheio do mesmo modo que o denso, mas o próprio raro deve se tornar mais vazio que o denso. Mas a distinção entre ser cheio ou não cheio deve ser feita [assim]: se nem dá lugar, nem recebe para dentro de si, é cheio. É necessário, portanto, que [o-que-é] seja cheio, se não houver vazio. Logo, se [o-que-é] é cheio, não se move.

Melisso sugere que a característica relativa entre o raro e o denso é a presença ou

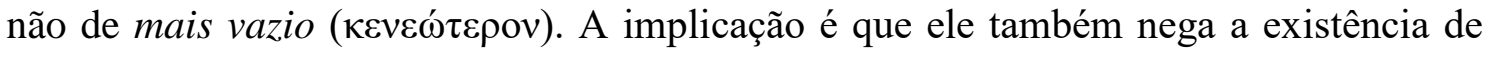
uma variação de densidade, pois nega o vazio. O que essa passagem está sugerindo é que 
variações de densidade implicariam na existência do vazio. Portanto o-que-é é cheio e o é de maneira total.

Melisso está negando a possibilidade de movimento em dois aspectos. A primeira

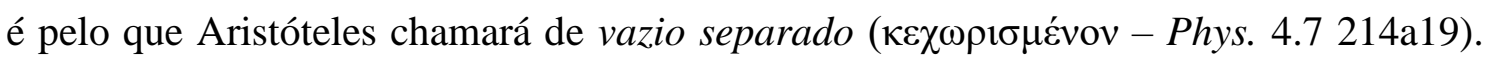
Isso é o que vimos na primeira parte em que ele diz que, se houvesse um vazio deste tipo, o cheio tenderia a mover-se para lá, por causa da liberação de um espaço de circulação. A segunda é pela diferença de densidade, que implica em um vazio não-separado

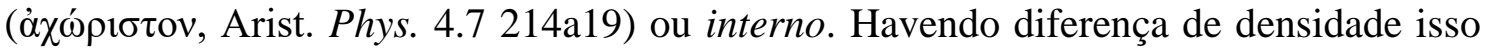
poderia gerar um tipo de movimento de penetração em que uma coisa menos cheia (isto

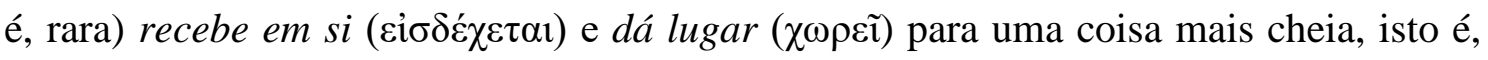
densa. A diferença entre esses dois tipos de movimento parece estar no verbo que Melisso

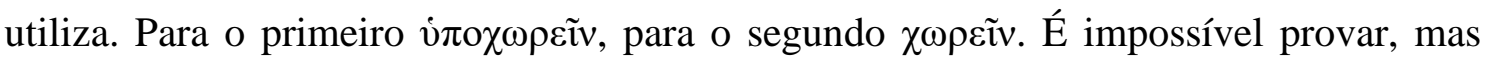
talvez, o prefixo vंлo- queira indicar justamente que, no primeiro caso, o espaço liberado seja absoluto e independente daquilo que se move (que, ademais, é uno), ao passo que no segundo caso isso não é necessário, pois há interpenetração de pelo menos duas coisas. ${ }^{27}$

\section{Sintese}

Aristóteles vê o vazio de seus predecessores como assemelhando-se a um recipiente

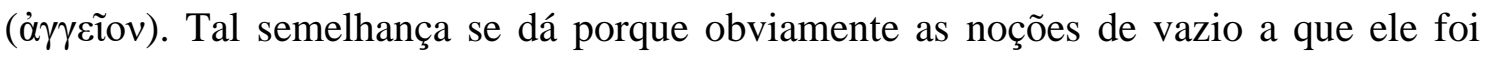
exposto e a ideia de recipiente têm semelhanças. Mas quais? A principal delas certamente é a função de todo e qualquer recipiente: a capacidade de receber, que é denotada pelo

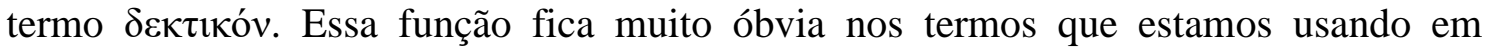
português: receber e recipiente, pois, a relação está marcada no radical. Em grego, isso

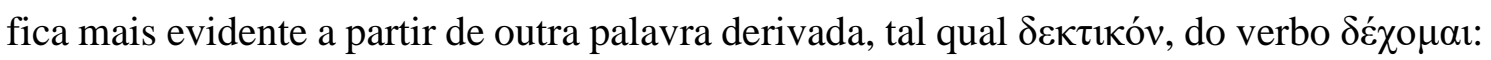

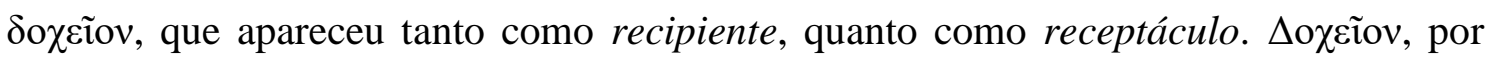
sinal, (e variantes) parecem ter sido usados pelo próprio Demócrito não apenas com o

\footnotetext{
${ }^{27} C f$., porém, Sedley, 1982, p. 178-179, que sugere que os dois verbos devem ser lidos com o sentido de 'give way', ou seja, ceder. Não fazer nenhum tipo de distinção entre os dois verbos, porém, ao contrário do que ele diz - que aqueles que interpretam a primeira passagem como sendo espacial ignoram a parte referente ao raro e ao denso -, não só deixa em aberto a questão "por que usar dois verbos, então?" como também torna a parte sobre o raro e o denso redundante. É justamente na segunda passagem que Melisso muda o seu vocabulário para falar do que aconteceria internamente a um corpo qualquer que fosse raro: ele receberia para dentro de si o corpo denso. Não há menção ao ato de receber nem o uso de qualquer termo derivado de $\delta \varepsilon ́ \chi 0 \mu \alpha \imath$ na primeira passagem.
} 
sentido concreto de um recipiente físico, mas talvez até num sentido metafórico. O que pode indicar que a noção de um princípio de recepção poderia estar presente em outros domínios para além do físico.

A ideia de recipiente aparece em vários âmbitos da investigação de autores antigos.

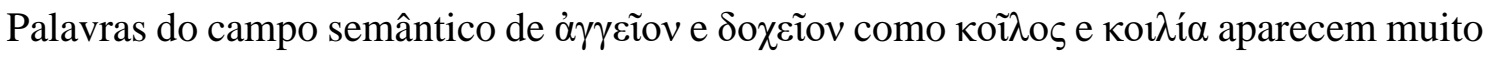
em descrições fisiológicas, geológicas, cosmogônicas e cosmológicas, e até mesmo como princípios elementares gerais de uma física empedocleana "atomicizada". Nos alimentamos através de um órgão oco capaz de receber e processar alimentos. Os nutrientes, por sua vez, se distribuem pelo corpo por causa de uma rede de pequenos vasos intercomunicantes que realizam o transporte de nutrientes e do ar que respiramos (com o auxílio de outro órgão oco fundamental - o pulmão) para todas as partes do corpo. De modo semelhante, se a água brota do chão é porque abaixo do chão existem como que reservatórios de água, redes ocas de túneis por onde a água passa movimentando-se o tempo todo. Movimento que, aliás, é capaz de desestabilizar a própria terra, provocando terremotos. De modo análogo, o fogo por trás do raio e do relâmpago circula por entre as nuvens, encontrando caminho nos espaços livres até se concentrar nas regiões ( $\chi \omega ́ \rho \alpha \imath)$ mais abundantes em vazios. E a própria formação do mundo depende do movimento de massas fluidas de líquidos e gases que são capazes até mesmo de escavar e moldar a terra por onde passam. Líquidos e gases, por sua vez, são definidos pela maior ou menor presença de um princípio análogo aos diferentes tipos de ocos que ocorrem no mundo.

Um recipiente é por definição um oco, ou seja, um vazio que pode vir ou não a ser cheio. O oco, por sua vez, é uma região tridimensional, um volume sem massa. É muito difícil não reconhecer nisso, nem chamar essa ausência de espaço. A presença dessas noções em diversos exemplos sugere que, contra Sedley, há, sim, uma noção subjacente de espaço entre os antigos. E não apenas isso, pois, como fica evidente pelo exemplo do Caos de Hesíodo, parece haver uma preocupação de que as coisas, para existirem, precisam de um certo espaço $(\chi \omega ́ \rho \alpha)$ em que possam estar. A possibilidade de um vazio parece emergir justamente da compreensão de que esse espaço não é parte nem dependente das coisas que o ocupam. Deverá, portanto, ser separado ( $\chi \omega \rho ı \tau$ ós,

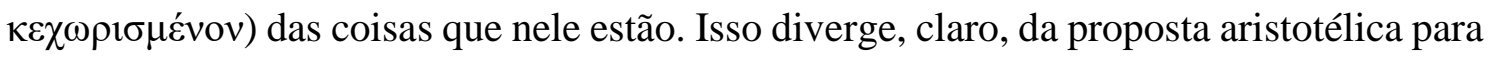
o lugar - divergência que ele mesmo deixa muito clara- mas tal espaço pode, se não em experiência, ao menos em tese ser pensado como um lugar ou região em que não há corpo (daí a definição de Aristóteles de vazio ser, em certa medida, bastante precisa). 


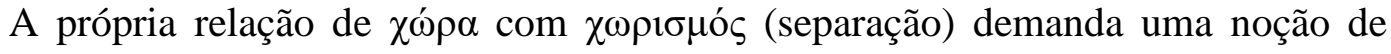
espaço, uma vez que $\chi \omega \rho ı \mu$ ó $\varsigma$ separa duas regiões ( $\chi \omega ́ \rho \alpha \imath)$ de um espaço, de modo que o sentido de separação empregado por Platão ao falar das formas, independentemente do estatuto ontológico das mesmas, já é por si só metafórico: separa o que pertence ou não ao domínio das coisas que se encontram no espaço (ou no Caos de Hesíodo para os crentes).

Há também, porém, e, diante das analogias fisiológicas, talvez primariamente, um

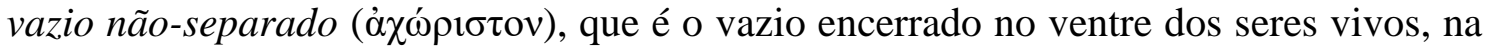
terra e nas nuvens, e também o vazio do que é raro, leve e sutil. Para esses, a noção de recipiente funciona perfeitamente, porque um recipiente é algo delimitado, com bordas, que limitam e demarcam aquilo que ele contém.

$\mathrm{Na}$ verdade, o próprio vazio separado pode compartilhar também desta característica que é a presença dos limites. Para muitos pensadores antigos, o cosmos é limitado e as coisas que nele existem estão efetivamente ali contidas. Mas há uma outra corrente que pensa em um ilimitado, infinito, indeterminado, começando em Anaximandro e culminando, em Leucipo e Demócrito. Ainda assim, mesmo um vazio ilimitado e infinito como o de Demócrito não perde a característica principal de um recipiente que é a de ser capaz de receber. Ele recebe os átomos, tanto no sentido de ser o palco onde eles atuam, quanto no sentido de que não impede sua atuação (isto é, sua movimentação).

Entretanto, diante da analogia com a noção de recipiente, parece ser mais razoável supor que Aristóteles parte primeiro da noção de um vazio interno e limitado, porque ela tende a ser mais compreensível e menos controversa do que a de um vazio separado e ilimitado, a respeito do qual pesarão as dificuldades que ele elencou em sua discussão sobre o infinito (Phys. 3.4-8).

Por outro lado, isso que é chamado de vazio também figura como uma negatividade elementar, primeiramente do que é corpo, mas também com outras possibilidades, opondo-se talvez à própria necessidade de determinação, como as negatividades não espaciais associadas ao vazio ou à noção de recipiente que aparecem, como vimos, em Demócrito, mas também em Filolau. ${ }^{28}$

\footnotetext{
${ }^{28}$ O presente trabalho foi realizado com apoio da Coordenação de Aperfeiçoamento de Pessoal de Nível Superior - Brasil (CAPES) - Código de Financiamento 001. Quero deixar também um agradecimento aos pareceristas que analisaram minha submissão por sua leitura atenta e críticas
} 
Gustavo Laet Gomes

Universidade Federal de Minas Gerais

\section{Referências Bibliográficas}

Angioni, L. (2008). Aristóteles. Metafísica: Livros I, II e III. Campinas: Unicamp. Cadernos de Tradução $n^{\circ} 15$.

Bailey, C. (1926). Epicurus. The Extant Remains. With short critical apparatus, translation and notes. Oxford: Clarendon Press.

Beekes, R. (2010). Etymological Dictionary of Greek. 2 vols. Leiden/Boston: Brill.

Caruso, F. (trad.) (2017). Plutarco. Opinioni dei filosofi sulla natura. Libri IV-V. In: Lelli, E.; Pisani, G. (coord.). Plutarco. Tutti i Moralia. Milano: Bompiani, p. 1726-1759.

Coulon, V.; Van Daele, M. (1928). Aristophane. Vol. 3. Paris: Les Belles Lettres. (Repr. 1967 (1st edn. corr.)) (Available at: http://stephanus.tlg.uci.edu)

Diels, H. (1952). Die Fragmente der Vorsokratiker. 6th ed. (rev. by Walther Kranz). Berlin: Weidmann. (1st ed. 1903)

Diels, H. (ed.) (1965). Doxographi graeci. 4ed. Berlin: Walter de Gruyter. (1ed 1879)

Diels, H.; Kranz, W. (2012). I Presocratici. Tradução de Giovanni Reale; Diego Fusaro, et al. $4^{\mathrm{a}}$ ed. Milano: Bompiani.

Dover, K. J. (1968). Aristophanes. Clouds. Oxford: Clarendon Press. (Repr. 1970) (Available at: http://stephanus.tlg.uci.edu)

Einarson, B.; De Lacy, P. H. (1967). Plutarch's Moralia. With an English Translation. Vol. 14 (1086C-1147A). Cambridge-Mass./London: Harvard University Press/William Heinemann. (Loeb Classical Library 428)

Hickie, W. J. (1853). Aristophanes. Clouds. The Comedies of Aristophanes. London/Bohn: Publisher Not Informed. (Available at: http://www.perseus.tufts. edu/hopper/text?doc=Perseus: text:1999.01.0241)

Hense, O. (ed.) (1912). Ioannis Stobaei. Anthologii. Libri duo prosteiores. Vol. 3. Berolini: Weidmannos.

Hooker, M. (2017). John Lydus. On the Months (De Mensibus). Translated with introduction and annotations. 2. ed. (Disponibilizado pelo autor online em https://archive.org/details/JohnLydusOn TheMonthsTr.Hooker2ndEd.2017)

Hussey, E. (1993). Aristotle. Physics. Books III and IV. Translated with Introduction and Notes. Oxford: Clarendon Press.

Jebb, R. C. (1905). Bacchylides. The Poems and the Fragments. Edited with Introduction, Notes, and Prose Translation. Cambridge: Cambridge University Press.

Laks, A.; Most, G. W. (2016). Early Greek Philosophy. 9 vols. Cambridge: Harvard University

importantes que contribuíram para deixar o texto mais objetivo e correto. Eventuais erros que ainda restarem são naturalmente de minha inteira responsabilidade. 
Press. (Loeb Classical Library 524-532)

Leszl, W. (2009). I Primi Atomisti. Raccolta dei testi che riguardano Leucippo e Democrito. Firenze: Leo S. Olschki.

Liddell, H. G.; Scott, R.; Jones, H. S.; Mckenzie, R. (1996). A Greek-English Lexicon. 10th ed. Oxford: Oxford University Press. (Available at http://www. perseus.tufts.edu/hopper/search)

Littré, É. (1853). Oeuvres complètes d'Hippocrate. Traduction nouvelle avec le text grec em regard. Vol. 8. Paris: J. B. Baillière.

Lopes, R. Platão. (2012). Timeu-Crítias: Tradução do grego, introdução e notas. $2^{\mathrm{a}}$ ed. São Paulo: Annablume.

Luria, S. Y. (2014). Democrito. Tradução de Diego Fusaro e Anastasia Krivushina. $2^{\mathrm{a}}$ ed. Milano: Bompiani.

Morel, P.-M. (1996). Démocrite et la recherche des causes. Paris: Klincksieck.

Morrison, B. (2002). On Location. Aristotle's Concept of Place. Oxford: Clarendon Press.

O’Neil Jr., E. (1938). Aristophanes. Birds. The Complete Greek Drama, vol. 2. New York: Random House. (Available at: http://www.perseus.tufts.edu/hopper/text? doc=Perseus:text: 1999.01.0026)

Prignano, S. (trad.) (2017). Plutarco. Opinioni dei filosofi sulla natura. Libro III. In: Lelli, E.; Pisani, G. (coord.). Plutarco. Tutti i Moralia. Milano: Bompiani, p. 1714-1725.

Primavesi, O. (2012). Metaphysics A: A New Critical Edition. In: Steel, C. (ed.). Aristotle's Metaphysics Alpha. Symposium Aristotelicum. Oxford: Oxford University Press. p. 387-515.

Puente, F. R. (2011). Os argumentos de Aristóteles contra o vazio (Phys. IV 8). In: Palumbo, L. (org.). Logon didonai. La filosofia come esercizio del render ragione. Studi in onore di Giovanni Casertano. Napoli: Loffredo, p. 777-790.

Radice, R. (2011). Aristotele. Fisica. Introduzione, traduzione, note e apparati. Milano: Bompiani.

Reeve, C. D. C. (2018). Aristotle. Physics. Translated with Introduction and Notes. Indianapolis/Cambridge: Hackett Publishing Company.

Rocchi, M. (trad.) (2017). Plutarco. Opinioni dei filosofi sulla natura. Libro I. In: Lelli, E.; Pisani, G. (coord.). Plutarco. Tutti i Moralia. Milano: Bompiani, p. 1674-1697.

Ross, W. D. (1950). Aristotelis Physica. Oxford: Clarendon Press. (Repr. 1966; 1st ed. corr.) (Available at: http://stephanus.tlg.uci.edu)

Ross, W. D. (1955). Aristotle. Parva naturalia. Oxford: Clarendon Press. (Repr. 1970.) (Available at: http://stephanus.tlg.uci.edu)

Ross, W. D. (1957). Aristotelis Politica. Oxford: Clarendon Press. (Repr. 1964.) (Available at: http://stephanus.tlg.uci.edu)

Ross, W. D. (1961). Aristotle. De anima. Oxford: Clarendon Press. (Repr. 1967.) (Available at: http://stephanus.tlg.uci.edu)

Sedley, D. (1982). Two Conceptions of Vacuum. Phronesis 27, n. 2, p. 175-193.

Shiffman, M. (2011). Aristotle. De Anima. Translated with Introduction and Notes. Focus, Newburyport.

Solmsen, F. (1960). Aristotle's System of the Physical World. A Comparison with His Predecessors. Ithaca: Cornell University Press.

Stallings, A. E. (2007). Lucretius. The Nature of Things: Translation. London: Penguin Classics. Usener, H. (1887). Epicurea. Lipsiae: B. G. Teubneri (Repr. 2010. Cambridge: Cambridge 


\section{University Press.)}

Veloso, C. W. (2017). Aristóteles. Meteorológicos. Tradução, Introdução e Notas, com a colaboração de Hiteshkumar Parmar. Lisboa: Imprensa Nacional.

Wachsmuth, C. (ed.) (1884). Ioannis Stobaei. Anthologii. Libri duo priores, qui inscribi solent Eclogae physicae et ethicae. 2 vols. Berolini: Weidmannos. 